Revista Thema

\begin{tabular}{l|l|l} 
v.19 & n.3 & 2021
\end{tabular} p.531-561

\title{
A trajetória acadêmica dos estudantes do curso técnico de Gestão Cultural do IFSul - Câmpus Sapucaia do Sul
}

\section{The academic trajectory of the students of the technical course of Cultural Management of IFSul - Sapucaia do Sul Campus}

Paloma Almeida Arce ${ }^{1}$, Walter Romeu Bicca Junior ${ }^{2}$

\section{RESUMO}

São recorrentes os casos de evasão, retenção e abandono escolar atualmente. A vista disso, esse artigo busca elucidar essa problemática, apresentando não apenas as causas e consequências, mas também um estudo aprofundado dos estudantes do curso técnico de Gestão Cultural integrado ao ensino médio do IFSul - Câmpus Sapucaia do Sul. Nesse estudo são apresentados dados do percentual de alunos evadidos, com matrículas trancadas e retidos dos cursos técnicos de Gestão Cultural. Além disso, foi analisado todos os anos, da primeira turma a se formar até a última de todos elas. O estudo dessa temática é de suma importância pois afeta a sociedade como um todo, não apenas as escolas, famílias e os estudantes.

Palavras-chave: Evasão escolar; abandono escolar; retenção escolar.

\section{ABSTRACT}

There are recurring cases of evasion, retention and dropping out of school today. In view of this, this article seeks to elucidate this problem, presenting not only the causes and consequences, but also an in - depth study of the students of the technical courses of Cultural Management integrated to the high school of IFSul - Campus Sapucaia do Sul. In this study data are presented of the percentage of students escorted, and withheld from the technical courses of Cultural Management. In addition, it was analyzed every year, from the first class to graduate to the last of them all. The study of this theme is of paramount importance as it affects society as a whole, not just schools, families and students.

Keywords: School evasion; school dropout; school retention.

\section{INTRODUÇÃO}

A Lei no 11.892 de 29 de dezembro de 2008 instituiu a Rede Federal de Educação Profissional, Científica e Tecnológica e cria os Institutos Federais de Educação, Ciência

${ }^{1}$ Instituto Federal de Educação, Ciência e Tecnologia Sul-rio-grandense, Câmpus Sapucaia do Sul/RS Brasil. E-mail: palomaarces@outlook.com

${ }^{2}$ Idem. E-mail: walterjunior@sapucaia.ifsul.edu.br 
e Tecnologia. Por meio desta, foram criados os Institutos Federais existentes em todos os estados do Brasil, substituindo os Centros Federais de Educação Profissional e que anteriormente eram chamadas de Escolas Técnicas Federais.

O Câmpus Sapucaia do Sul teve sua origem como uma Unidade Descentralizada (UNED) da então Escola Técnica Federal de Pelotas (ETFPel). Em sua criação, a unidade possuía a formação na área de Plásticos como a sua principal. Já como UNED do Centro Federal de Educação Tecnológica (CEFET), a unidade implementou outros cursos. No contexto da época, surgiu um curso desafiador, o Curso Técnico Integrado em Gestão Cultural, na qual tinha uma formação em uma área diferente das propostas até então. O desafio também era considerado pelo próprio perfil do corpo docente, na qual visava uma formação técnica considerada mais "rígida":

O curso Técnico em Gestão Cultural forma profissionais que atuarão na elaboração e execução de projetos de eventos, com base no referencial econômico contemporâneo. O curso possui ênfase em eventos culturais, cuja demanda é crescente em virtude das necessidades atuais do mercado. Esse profissional pode assessorar, coordenar e conduzir grupos de trabalho para execução de serviços de apoio técnico e logístico em todas as etapas dos eventos, considerando a sustentabilidade ambiental, social, econômica e cultural. O técnico em eventos também pode gerenciar e executar projetos conforme a necessidade de organizações públicas e privadas. (IFSul, 2018).

O curso precisou ser extinto pois não estava incluído no catálogo de cursos do Ministério da Educação, apesar de possuir o reconhecimento do mercado de trabalho da área de formação. Após o encerramento do curso é importante uma avaliação desta formação, elencando diversos elementos, dentre eles o reconhecimento da comunidade pela formação. Esses índices podem ser diagnosticados considerando as informações sobre acesso, retenção e evasão ao longo da oferta dessa formação. "A evasão escolar na Educação Profissionalizante representa uma problemática que afeta a formação e o desenvolvimento do jovem ou adulto que almeja se qualificar em busca de melhores empregos e qualidade de vida." (ARAÚJO; SANTOS, 2012). Além de prejudicar a vida do aluno evadido, sendo este um problema no âmbito pessoal, acarreta também em consequências nacionais que afetam todos os cidadãos, como o investimento público que se perde toda vez que um estudante abandona a escola.

De acordo com as ocorrências preocupantes de evasão escolar em nossas escolas, nosso objetivo foi verificar os índices de evasão, retenção e conclusão do curso técnico integrado em Gestão Cultural no IFSul - câmpus Sapucaia do Sul. Na coleta de dados, foram analisados os estudantes que ingressaram no Curso Técnico Integrado em Gestão Cultural entre os anos de 2008 e 2012. Os dados foram separados em conclusão do curso, evasões, transferências externas, trancamento de matrícula e também reprovações dos alunos.

Ao realizarmos essas análises poderemos dispor de dados para o diagnóstico sobre as vagas que ofertamos e combater as questões de evasão e retenção. A importância da pesquisa poderá ser verificada ao podermos dar continuidade na análise sobre as razões pelas quais os estudantes tenham evadido ou retido e dessa forma elaborarmos ações para combater índices altos de evasão/retenção se for o caso. 


\section{FUNDAMENTAÇÃO TEÓRICA}

\subsection{EVASÃO ESCOLAR}

A evasão escolar é certamente uma das principais barreiras que impedem e dificultam a introdução de uma rotina acadêmica na vida das pessoas. De acordo com a pesquisa de Silva Filho (2007), o índice de evasão média da Educação Básica foi de $11 \%$, sendo que nas instituições privadas foi de $3,6 \%$, nas federais foi de $5,6 \%$, nas municipais foi de $9,4 \%$ e, por fim, nas estaduais $12,2 \%$. Estes índices vêm motivando cada vez mais a realização de pesquisas no intuito de investigar os motivos pelos quais os estudantes estão abandonando a escola. Tornar público os índices e as ocorrências crescentes nos dados relacionados à evasão escolar são importantes, tendo em vista que a saída de alunos precocemente pode trazer consequências nas instituições públicas de ensino, o desperdício de investimentos e nas privadas perdas de receitas.

Para Johann (2012), a evasão pode ser entendida como um fenômeno caracterizado pelo abandono do curso, que rompe com o vínculo estabelecido, não renovando o compromisso ou sua manifestação de continuar no estabelecimento de ensino. Tal situação de evasão é vista como abandono, onde não há a intenção de voltar, levando em consideração que, não renovando a matrícula, rompe-se o vínculo existente entre aluno e escola.

Há, ainda, a distinção entre dois conceitos: a evasão do curso - que consiste no abandono do curso sem a sua conclusão - e a evasão do sistema - que reflete o abandono do aluno do sistema universitário. (POLYDORO, 2000). Além desta distinção, Cardoso (2008) refere-se aos conceitos acima a partir de duas nomenclaturas: a evasão aparente - mobilidade do aluno de um curso para outro - e a evasão real referente à desistência do aluno em estudar outro curso.

Conforme Silva Filho e Araújo, o Instituto Nacional de Estudos e Pesquisas Educacionais Anísio Teixeira (INEP) apresenta distinções entre dois termos recorrentes e similares: evasão e abandono escolar.

A diferença entre evasão e abandono escolar foi utilizada pelo Instituto Nacional de Estudos e Pesquisas Educacionais Anísio Teixeira/Inep (1998). Nesse caso, "abandono" significa a situação em que o aluno desliga-se da escola, mas retorna no ano seguinte, enquanto na "evasão" o aluno sai da escola e não volta mais para o sistema escolar. (SILVA FILHO; ARAÚJO, 2017, p.37).

Os índices de casos de abandono escolar a nível profissional preocupam, tendo em vista que estes explicam o fato das baixas qualificações e habilidades profissionais apresentados pelos jovens na concorrência do mercado de trabalho. Outra razão que explica estes casos é a dificuldade encontrada por alguns estudantes em se inserirem na modalidade de ensino profissional.

A evasão escolar é um tema atual e que preocupa muitos profissionais na área de educação e nas instituições de ensino. Através da leitura de textos, artigos e teses, percebe-se que os estudos estão voltados para a evasão escolar do ensino fundamental e médio. Existem, portanto, poucos estudos voltados para o ensino técnico e superior. (CRAVO, 2012, p.242), 
Um dos fatores que mais preocupam com relação às ocorrências da evasão no ensino técnico e profissional é o fato da evasão nesta modalidade refletir significativamente na busca por melhores empregos e melhor qualidade de vida. "A evasão escolar na educação profissionalizante representa uma problemática que afeta a formação e o desenvolvimento do jovem ou adulto." (ARAÚJO; SANTOS, 2012). Como cita Meira (2015) em sua dissertação, "sendo assim, constitui um problema de ordem democrática em que o direito à permanência do aluno na escola não está sendo garantido".

Devido ao grande número de pesquisas referente ao tema da evasão escolar, é possível encontrarmos diversas causas em variados âmbitos. Além disso, a partir das mesmas, é possível também identificarmos diversos agentes e a forma com que eles agem.

No entanto, [...] uma série de estudos empíricos, oriundos de disciplinas das Ciências Sociais, tem distinguido dois tipos de fatores: os individuais, relacionados aos próprios alunos, suas atitudes, comportamentos, desempenho escolar e experiências anteriores; e os contextuais, que se associam às famílias dos estudantes, às escolas e às comunidades em que vivem. (MACHADO; MOREIRA, 2017, p.361).

A causa mais comum das ocorrências de evasão escolar está ligada com a baixa renda e a necessidade de inserção no mercado de trabalho. Todavia, é um erro minimizar a existência de causas acadêmicas levarem os jovens a desistirem dos estudos. Resultados ineficazes e expectativas frustradas com o curso podem desmotivar o aluno a permanecer e persistir no caminho da educação.

Outro importante insumo da produção de educação é o tempo utilizado pelos indivíduos nessa atividade, e que deixa de ser aproveitado em oportunidades eventuais no mercado de trabalho. De outro modo, quanto mais atraentes as alternativas de trabalho para os indivíduos em idade de estudar, menos atrativos serão os estudos e maior será o impacto das restrições de crédito sobre o grau de subinvestimento em capital humano. (SANTOS et al., 2000, p.13).

De acordo com a pesquisa feita por Gaioso (2010), problemas como: falta de orientação vocacional, imaturidade do estudante, reprovações sucessivas, dificuldades financeiras, falta de perspectiva no trabalho, ausência de engajamento com a escola, imposição familiar na decisão de ingressar na vida acadêmica, filhos, casamento, dentre outros, levaram os estudantes a desvincularem-se com 0 ensino profissionalizante.

Alguns aspectos podem servir de indicadores para que haja a identificação do problema antes que o mesmo ocorra. Notas baixas no início do processo educativo é um forte aspecto de previsão de futuro abandono; desempenho inadequado frequente costuma implicar reprovação; faltas, atos delinquentes e abuso de substâncias ilegais são fortes preditos de abandono. (RUMBERGER; LIMA, 2008).

De acordo com os resultados obtidos em seus estudos, Menezes-Filho e Leon (2003), é apresentado pelos autores que a reprovação colabora na perpetuação do problema da 
evasão escolar. "[...] a proporção de indivíduos que abandonaram os estudos é bem maior entre os repetentes do que entre os promovidos no curso." (MENEZES-FILHO; LEON, 2003).

\subsection{REPROVAÇÃO ESCOLAR}

A reprovação é um fator importante nas questões escolares, principalmente ao considerarmos fracasso e êxito. Segundo Moura e Silva (2012), quando abordamos o termo reprovação temos a impressão que se trata de um tema recente. Ao longo dos anos é tema de muitas discussões polêmicas e objeto de pesquisas sobre o fracasso escolar e suas prováveis causas nas escolas públicas brasileiras. Além disso, as autoras também relacionam reprovação com a rejeição, condenação, incapacidade que, em uma abordagem mais complexa e delicada, nega um ideal de sucesso, angustiando todos os envolvidos no processo, principalmente os alunos.

As autoras ainda enfatizam que antigamente não era levado em conta fatores inerentes ao indivíduo quando se analisava as causas de reprovação. Por outro lado, alguns grupos já defendiam que os indivíduos diferem entre si e a educação deveria ser adaptada a estas diferenças.

A psicologia não considerava as diferenças individuais ou as particularidades de cada um. Os estudos estavam voltados para os mistérios da mente humana. No ambiente escolar as causas das dificuldades estavam sempre localizadas no aprendiz e não se cogitava a ideia de que fatores relacionados à vida pessoal e familiar pudessem influenciar no desenvolvimento da aprendizagem do aluno. (MOURA; SILVA, 2012, p.5).

Para Fornari (2010), fatores determinantes da reprovação escolar e, posteriormente, uma possível evasão escolar são: desestruturação familiar, as políticas de governo, o desemprego, a desnutrição, a escola e a própria criança. Muito se acredita que uma das causas das ocorrências de reprovação escolar é a família, onde quanto mais baixo o nível de escolaridade dos pais, mais tempo o jovem permanece na escola. "Nesse sentido, a família é apontada como um dos determinantes da evasão e do baixo rendimento escolar, seja pelas suas condições de vida, seja por não acompanhar o aluno em suas atividades escolares." (FORNARI, 2010).

O autor destaca que a culpa da reprovação escolar é dada ao estudante, onde ele é culpado por seu fracasso, seja pela pobreza, seja pela desnutrição, seja pela falta de esforço, seja pelo desinteresse do mesmo. Culpar o estudante faz parte das teorias que explicam a ideologia do dom e a ideologia da deficiência cultural. Dessa forma, estas teorias buscam fazer com que as pessoas acreditem que o único responsável pelo sucesso ou fracasso social de cada um é o próprio indivíduo e não a organização social que o envolve.

Com efeito, esses são elementos importantes para compreender que a evasão e a reprovação escolar são fruto de um processo cumulativo, não se espera que filho de agricultor seja filósofo, assim como filhos de pais com insucesso escolar estão praticamente fadados a isso também. (FORNARI, 2010, p.117). 


\subsection{RELAÇÃO ENTRE REPROVAÇÃO E EVASÃO ESCOLAR}

Diversos autores, em suas produções e pesquisas, apontaram para a questão da reprovação ou reprovações sucessivas dos alunos levar os mesmos a evadirem do sistema escolar. Dessa forma, com tais reprovações, o aluno acaba por se sentir desmotivado e perder o interesse tanto na escola quanto nos estudos.

As dificuldades presentes no processo de educação escolar, em especial o desempenho precário e os problemas relacionais dos jovens, poderão comprometer o interesse pela escola. Além do mais, as sucessivas vivências de reprovações e de evasões podem levar ao abandono escolar. (NUNES et al., 2014, p.204).

De acordo com os resultados obtidos em seus estudos, Menezes-Filho e Leon (2003), apresentam que a reprovação colabora na perpetuação do problema da evasão escolar. "[...] a proporção de indivíduos que abandonaram os estudos é bem maior entre os repetentes do que entre os promovidos no curso." (MENEZES-FILHO; LEON, 2003). Já Queiroz (2006), parte da responsabilidade da evasão é do próprio indivíduo. A falta de interesse do aluno, a não participação do mesmo nas atividades escolares, a falta de perspectiva de vida e a defasagem de aprendizagem trazida das séries anteriores são algumas das possíveis causas de reprovação e, posteriormente, uma possível evasão escolar. Para a autora, apesar de a escola ser um ambiente para proporcionar educação e orientar o indivíduo para o futuro, pode também servir como um agente no problema da evasão escolar. Vejamos a visão da autora:

A má companhia, segundo eles, consiste, por um lado, na formação de grupos para conversas durante o período de aulas, e por outro, nas relações estabelecidas com outros jovens fora do ambiente escolar que acabam fazendo com que os alunos deixem de frequentar a escola ou de participar das atividades escolares. (QUEIROZ, 2006, p.7).

Entretanto, é um erro achar que apenas os repetentes ou aqueles com dificuldades nas disciplinas estão expostos a entrar nas estatísticas da evasão escolar. Os resultados obtidos e apresentados por Queiroz (2006) mostram a existência de alunos que apesar de participar e desenvolver com facilidade as atividades escolares, também evadem.

Ainda como exemplo de situações complexas e relacionadas à questão da evasão escolar, os resultados obtidos revelam a existência, de um lado, de alunos que, não somente diante de dificuldades ou de falta de interesse, abandonam a escola, mas também, de outro lado, aqueles que, apesar de participar e desenvolver com facilidade as atividades escolares, também evadem, ainda que por motivos diversos. (QUEIROZ, 2006, p.10).

Levando em consideração o supracitado, nem todos os repetentes consequentemente irão se tornar evadidos, bem como os aprovados não estão livres de evadir futuramente, mesmo não tendo motivos no âmbito acadêmico para isso. Tal fato comprova a existência de outras causas que levam o estudante a evadir, não sendo apenas o rendimento escolar.

[...] pode-se afirmar que, ainda que haja alguns fatores sociais internos e externos à Escola, e internos e externos à Família, a evasão escolar não 
protege aqueles que não se enquadram em qualquer um dos casos apontados na ótica dos adultos e na ótica das crianças. Isto significa dizer que nenhum aluno, para não dizer, nenhuma Família e nenhuma Escola, está invicta diante do monstro da evasão escolar. Isto porque, talvez, para além dos fatores determinantes externos ao sujeito, há que se levar em conta outro aspecto, aqueles internos, que se inserem na subjetividade destas crianças e adolescentes. (QUEIROZ, 2006, p.11).

Segundo dados divulgados por Garschagen na revista "Desafios" do Instituto de Pesquisa Econômica Aplicada (IPEA) em 2007, o percentual de repetência escolar brasileira é o segundo mais alto do mundo, menor apenas que o da Angola. " $A$ repetência afeta a autoestima das crianças, além de ser uma das principais causas do baixo rendimento e da evasão escolar."

Essas crianças, discriminadas e desmotivadas, aprendem menos ainda quando repetem a mesma série e acabam por abandonar a escola, mesmo quando gostam de frequentá-la, pela convivência com outras crianças da mesma idade. (GARSCHAGEN, 2007, p.37).

Forçar um aluno a repetir o ano, após meses de esforço a fim de aprender algo, em escolas com professores desmotivados e mal pagos, acaba por desanimar o aluno. A situação torna-se mais dramática quando esse mesmo aluno tem origem social humilde, com pais analfabetos e percebe que a maior parte dos colegas progrediu de ano. (GARSCHAGEN, 2007).

\section{METODOLOGIA}

Foi utilizado o método de pesquisa quali-quantitativa onde na parte qualitativa foi considerado Polydoro (2000). Compondo a parte quantitativa da pesquisa, foi feita uma coleta de dados a partir dos estudantes ingressantes de 2008 a 2012 no curso de Gestão Cultural. Os estudantes que ingressaram nos anos mencionados foram separados nas seguintes categorias (evadido, transferido, retido, concluiu no ano devido e se teve dependência) e as categorias foram cruzadas.

O total de estudantes analisados com a coleta de dados foi de 347, as informações utilizadas na análise quantitativa foram obtidas por meio da solicitação dos mesmos a Coordenadoria de Registros Acadêmicos (CORAC).

Quanto à sua classificação, esta pesquisa é caracterizada por pesquisa explicativa pois possui como objetivo entender e identificar as causas que levaram os estudantes a desistirem dos estudos e evadirem.

\section{RESULTADOS E DISCUSSÕES}

Com base na análise feita e, a partir dela, dos dados coletados do curso de Gestão Cultural nos anos de 2008 a 2012, tivemos os seguintes resultados:

O somatório de ingressos em todos os anos foi de 347 estudantes. Deste total, $68 \%$ (236) se formaram e 32\% (111) não se formaram na formação técnica em Gestão Cultural. Do total de não formados, 111, 60\% (67) evadiram, 20\% (22) cancelaram a 


\section{Revista Thema}

V.19

matrícula, 14\% (15) transferiram-se para outra instituição de ensino e 6\% (7) trocaram de grade.

Figura 1 - Situação dos estudantes ingressos no curso de Gestão Cultural do IFSul câmpus Sapucaia do Sul.

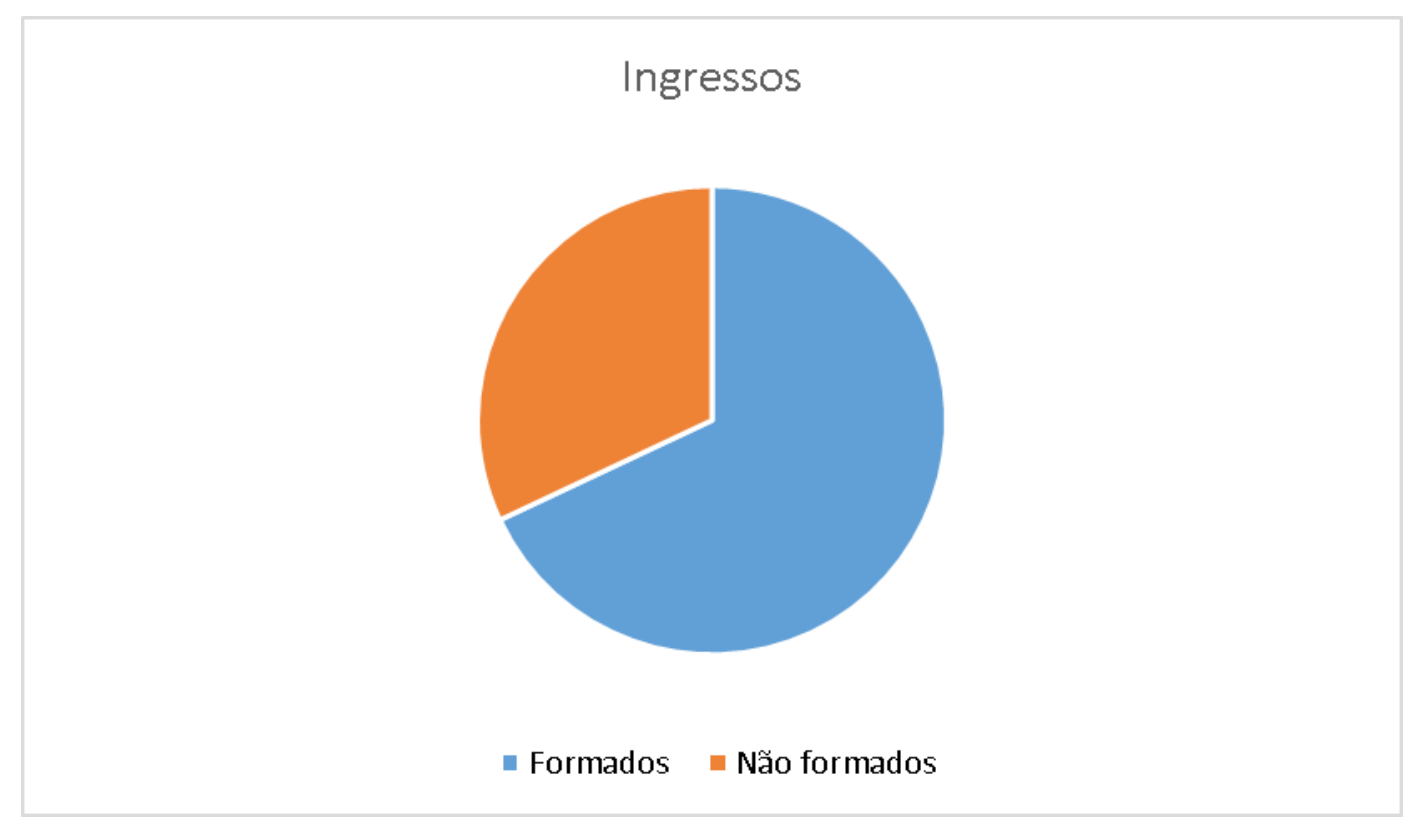

Fonte: Elaborada pelos autores.

Figura 2 - Situação dos estudantes não formados do curso de Gestão Cultural do IFSul câmpus Sapucaia do Sul.

\section{Não formados}

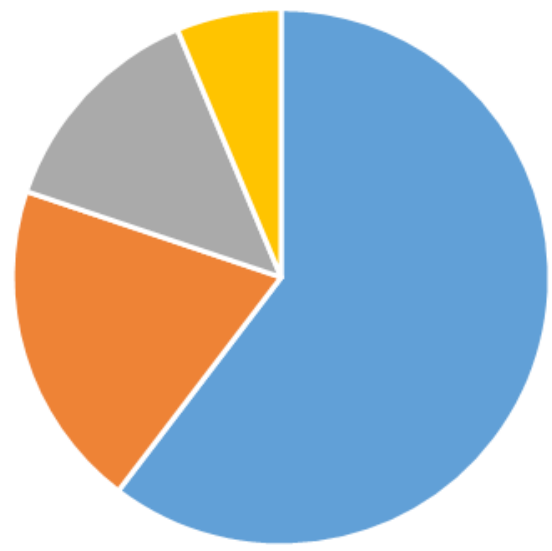

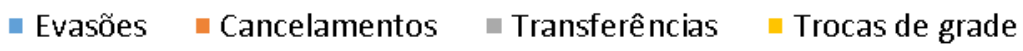

Fonte: Elaborada pelos autores. 


\section{Revista Thema}

A partir dos dados obtidos com a análise, em todos os anos analisados, a maior parte dos desligamentos teve relação com situações de reprovações e/ou dependências em disciplinas.

Considerando as informações sobre as reprovações, em todos os anos analisados foi observado que a maioria das reprovações ocorreu pela infrequência dos estudantes, indicando uma possível evasão. Vale ressaltar também que os casos de evasões com histórico de reprovação apontaram que os discentes evadidos possuíam reprovações em mais de 3 disciplinas no momento do abandono.

Os autores Menezes-Filho e Leon (2003) também apresentam em seus estudos que as ocorrências de evasões nas séries-diplomas, ou seja, último ano de curso, se dá em menor número se comparado com as demais séries. Corroborando com a ideia dos autores, a partir dos dados coletados, foi perceptível que a maioria dos desligamentos se deu no 1 ㅇ ano de curso e, contrapondo o primeiro, os desligamentos no 4 o ano ocorreram em menor número.

Figura 3 - Número total de desligamentos do curso técnico de Gestão Cultural do IFSul câmpus Sapucaia do Sul por ano.

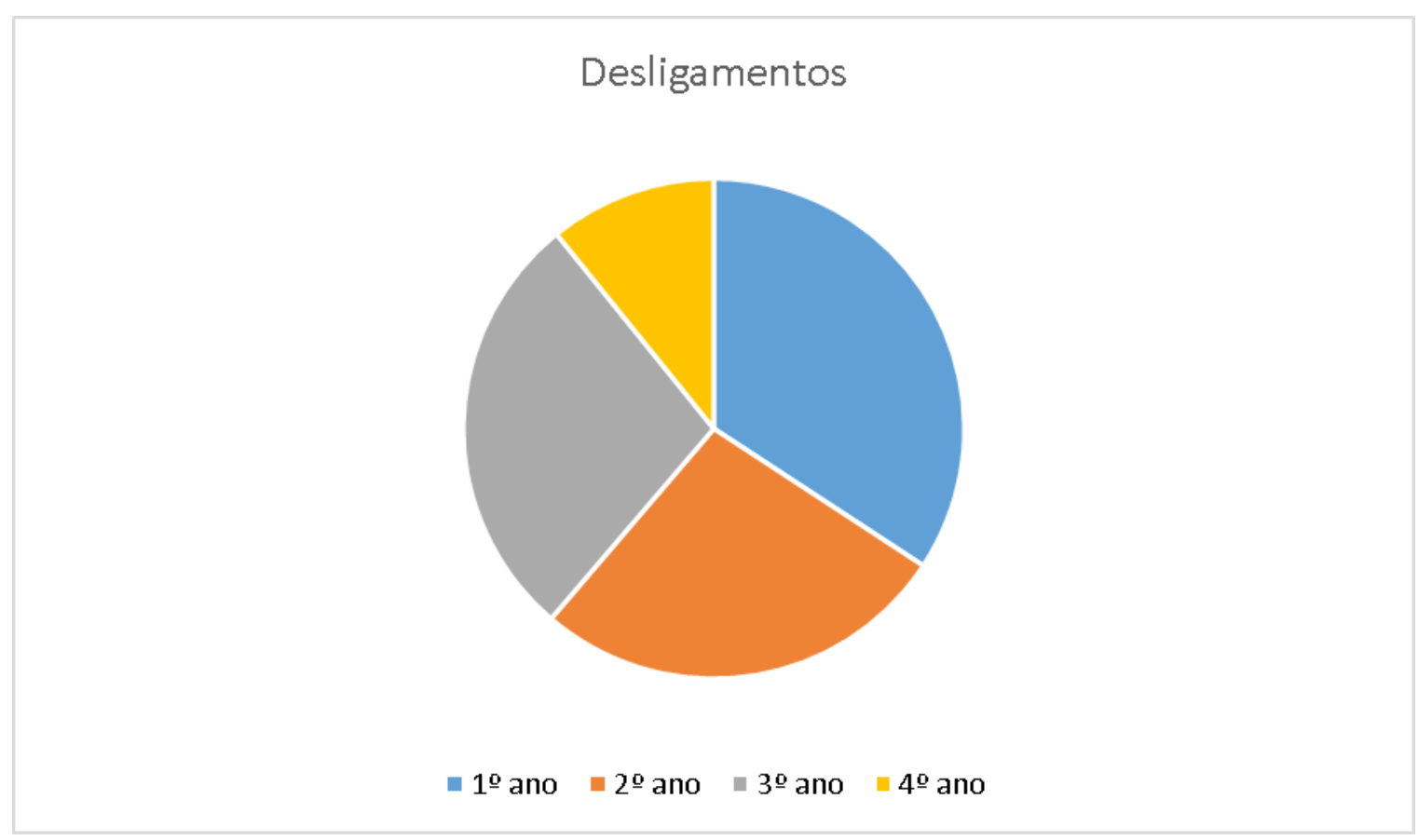

Fonte: Elaborada pelos autores.

\subsection{INGRESSO EM 2008}

Em 2008, o número de estudantes que ingressaram no curso foi de 70 estudantes. Deste total, o percentual de $57 \%$ (40 estudantes) se formou, o restante $43 \%$ (30 estudantes) não se formou. 


\section{Revista Thema}

Figura 4 - Situação dos estudantes ingressos em 2008 no curso técnico de Gestão Cultural do IFSul câmpus Sapucaia do Sul.

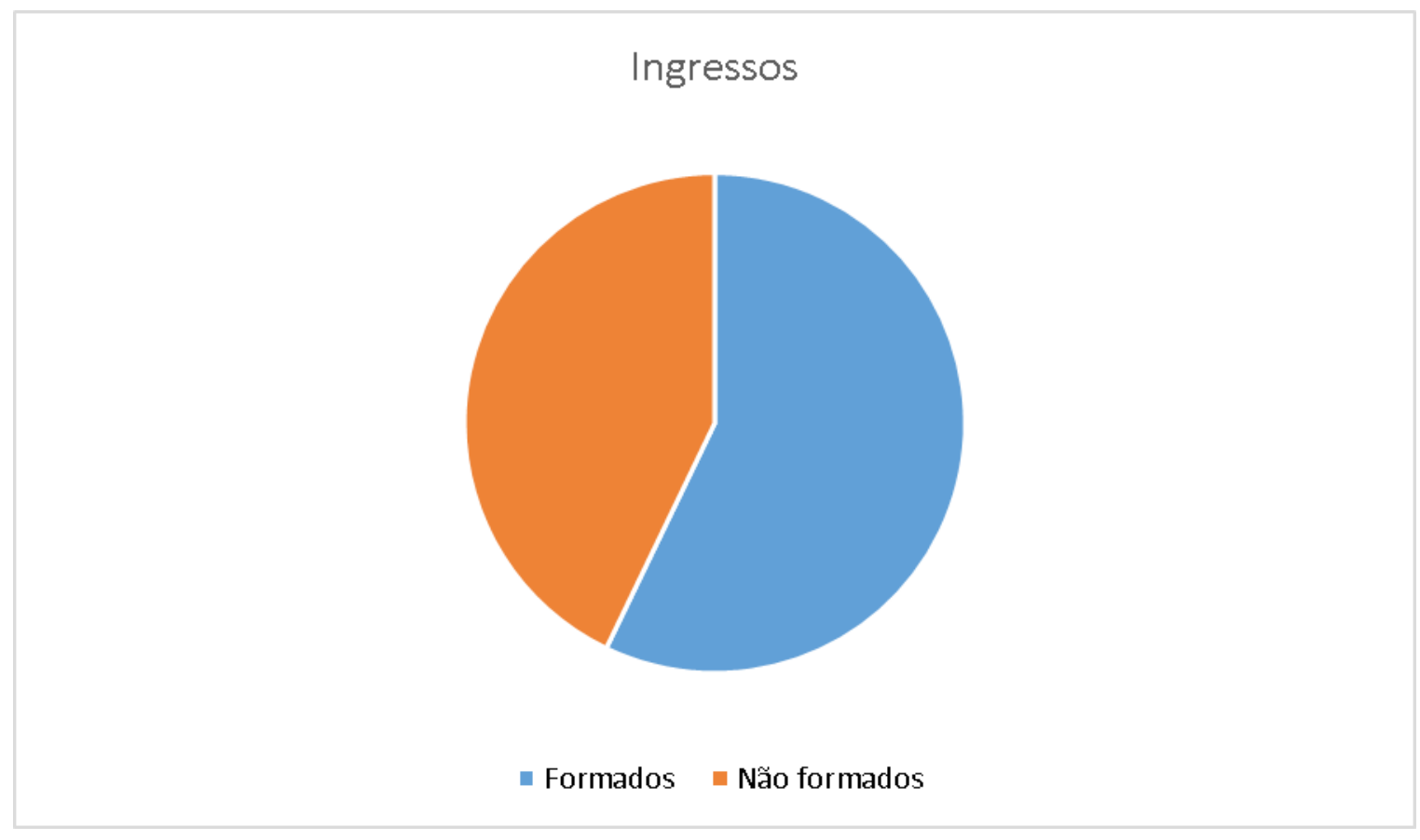

Fonte: Elaborada pelos autores.

Dos $43 \%$ de alunos que não se formaram, $77 \%$ (23) evadiram, $13 \%$ (4) cancelaram a matrícula, $7 \%$ (2) fizeram transferência e os 3\% (1) restantes fizeram o Exame Nacional do Ensino Médio (ENEM).

Figura 5 - Situação dos estudantes não formados em 2008 no curso técnico de Gestão Cultural do IFSul câmpus Sapucaia do Sul.

Não formados

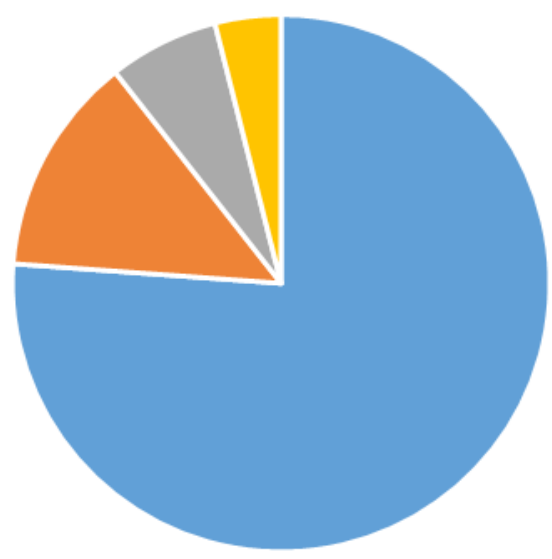

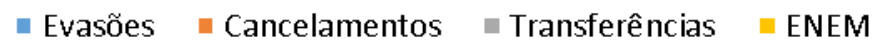

Fonte: Elaborada pelos autores. 


\section{Revista Thema}

V.19

\begin{tabular}{l|l} 
n.3 & 2021
\end{tabular}

O ano em que houve mais casos de desligamentos foi o 1 o ano (41\%) com 12 casos, seguido do 2 o ano (21\%) com 6 casos, logo depois do 3a ano (24\%) com 7 casos e, por fim, o último (14\%) com 4 casos.

Figura 6 - Número total de desligamentos em 2008 no curso técnico de Gestão Cultural do IFSul câmpus Sapucaia do Sul por ano.

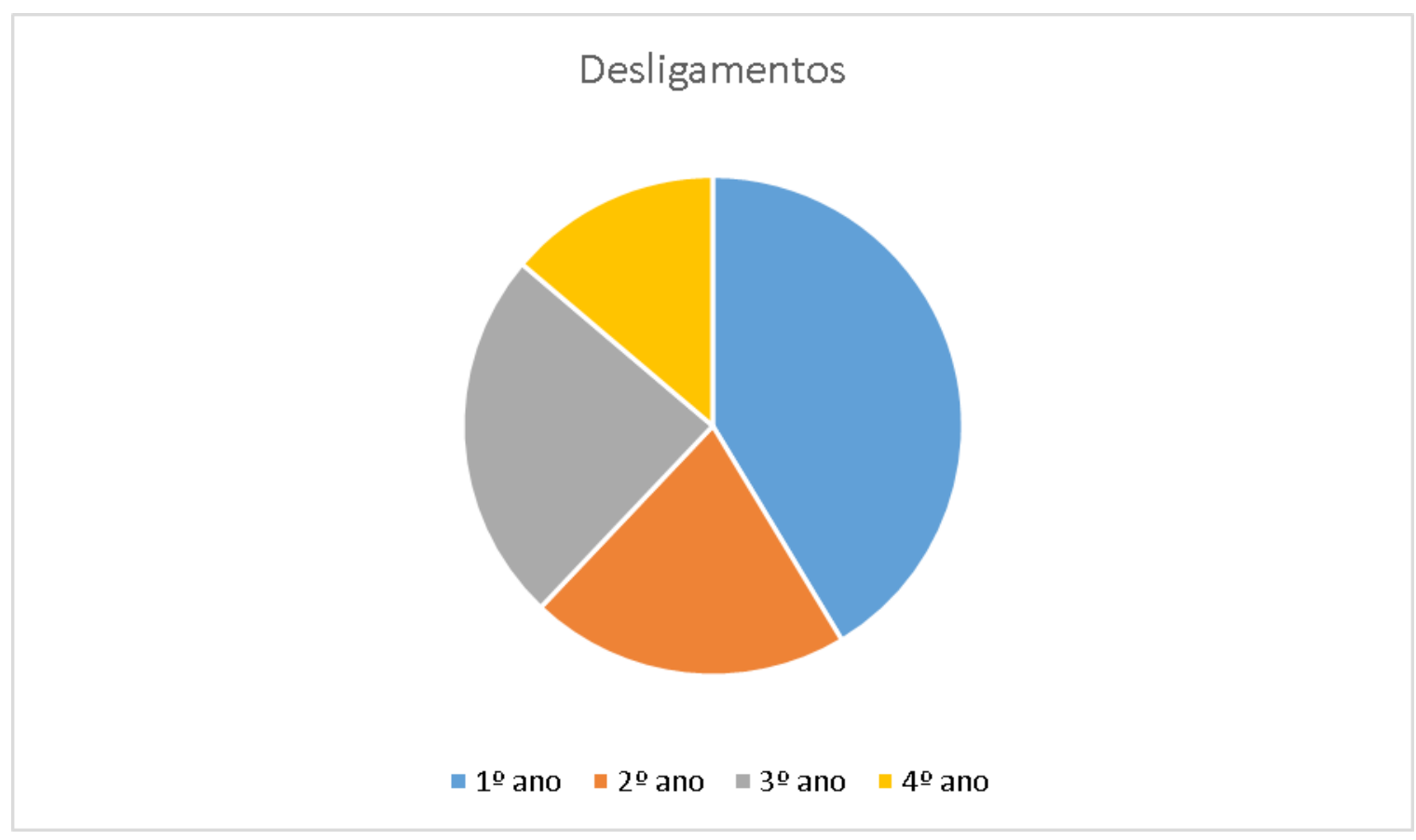

Fonte: Elaborada pelos autores.

Figura 7 - Situação dos estudantes evadidos em 2008 no curso técnico de Gestão Cultural do IFSul câmpus Sapucaia do Sul.

\section{Evasões}

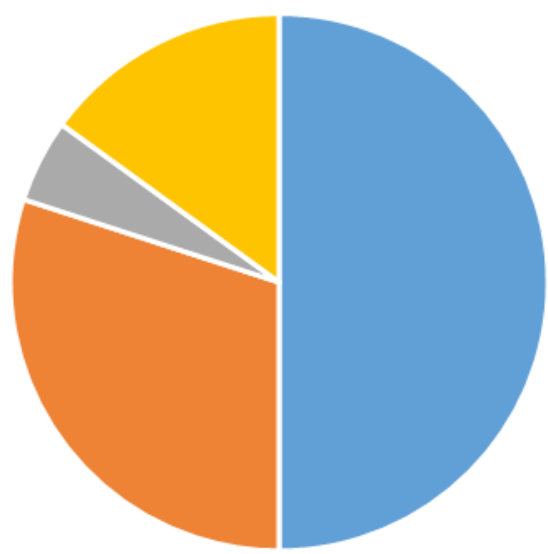




\section{Revista Thema}

Do total de $77 \%$ que evadiram, a maioria dos evadidos (44\%, 10 estudantes) tiveram alguma reprovação, $26 \%$ (6) dos evadidos tiveram alguma dependência com reprovação, $4 \%$ (1) dos evadidos não teve reprovação, $13 \%$ (3) dos evadidos estavam com dependência e, por fim, $9 \%$ (2) evadiram no primeiro ano, sem sequer ter reprovação ou dependência.

Do total de $13 \%$ de cancelados, o percentual ficou em equilíbrio. $25 \%$ (1) dos cancelados tinham dependência; 25\% (1) tinha reprovação; $25 \%$ (1) dos cancelados tinham aprovação e os $25 \%$ (1) restantes não tinham motivo.

Com relação aos transferidos externamente, de um total de $7 \%, 50 \%$ (1) possuía aprovação e os outros 50\% (1) era evadido.

Das reprovações no 1 o ano, a maior parte $(46 \%, 5$ estudantes) reprovou por infrequência; 36\% (4) tinham 3 disciplinas reprovadas; 9\% (1) tinham 4 disciplinas reprovadas; e o restante, $9 \%$ (1) tinham 6 disciplinas reprovadas. Das reprovações no 2 o ano, houve um equilíbrio. $50 \%$ (1) eram retidos e os outros $50 \%$ (1) tinham 7 disciplinas reprovadas. No 3o ano, 83\% (5) das reprovações eram de alunos retidos e $17 \%$ (1) tinham 7 disciplinas reprovadas.

Figura 8 - Situação dos estudantes com matrículas canceladas no curso técnico de Gestão Cultural em 2008 do IFSul câmpus Sapucaia do Sul.

\section{Cancelamentos}

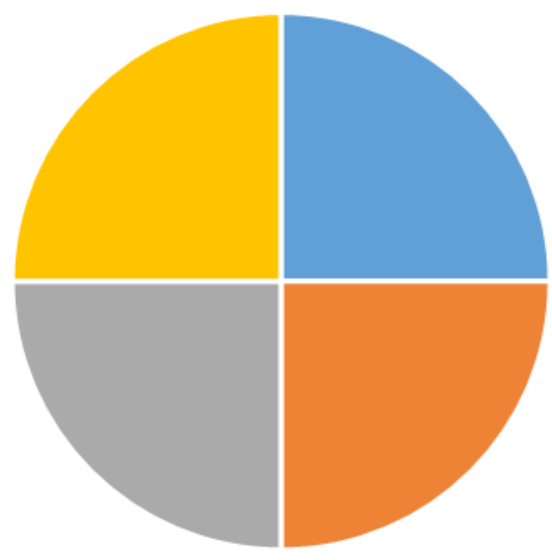

- Dependência " Reprovação " Aprovação " Sem motivos

Fonte: Elaborada pelos autores. 


\section{Revista Thema}

V.19

\begin{tabular}{l|l} 
n.3 & 2021 \\
\hline
\end{tabular}

Figura 9 - Situação dos estudantes com transferências externas em 2008 no curso técnico de Gestão Cultural do IFSul câmpus Sapucaia do Sul.

\section{Transferências externas}

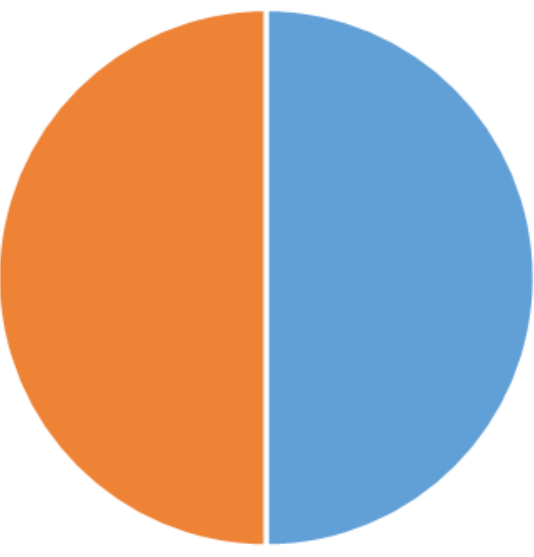

- Aprovações Evasões

Fonte: Elaborada pelos autores.

Figura 10 - Situação dos estudantes do 1 o ano do curso de Gestão Cultural em 2008 do IFSul câmpus Sapucaia do Sul.

\section{1ㅇ ano}

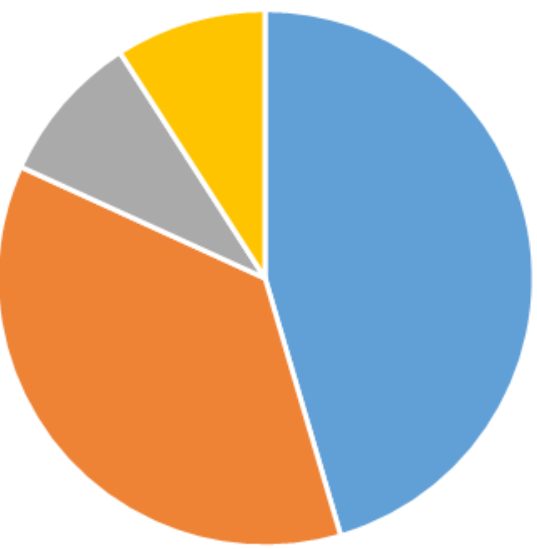

- Infrequências $\square 3$ reprovações $\quad 4$ reprovações $\quad 6$ reprovações

Fonte: Elaborada pelos autores. 


\section{Revista Thema}

Figura 11 - Situação dos estudantes do 2 o ano do curso de Gestão Cultural em 2008 do IFSul câmpus Sapucaia do Sul.

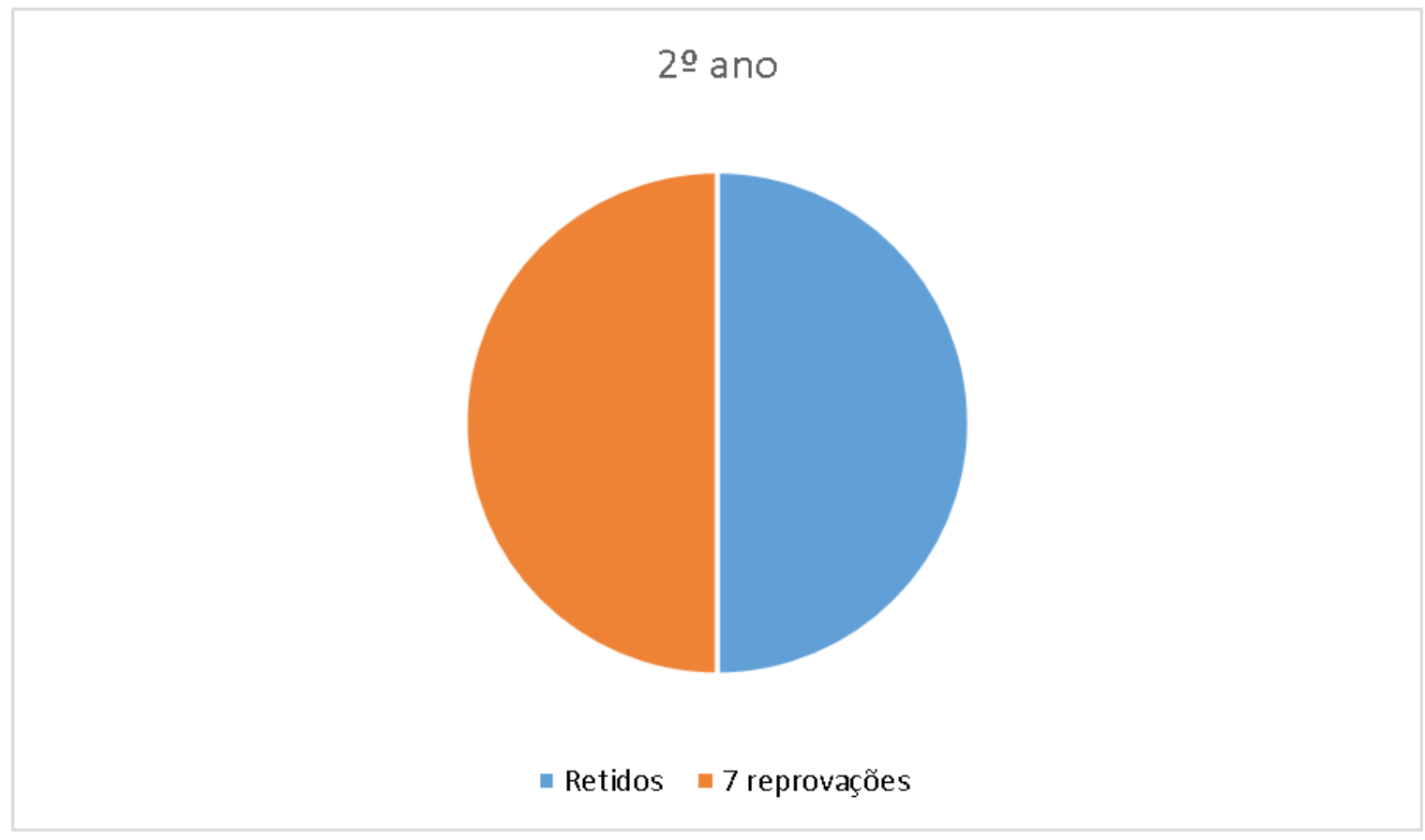

Fonte: Elaborada pelos autores.

Figura 12 - Situação dos estudantes do 3 o ano do curso de Gestão Cultural em 2008 do IFSul câmpus Sapucaia do Sul.

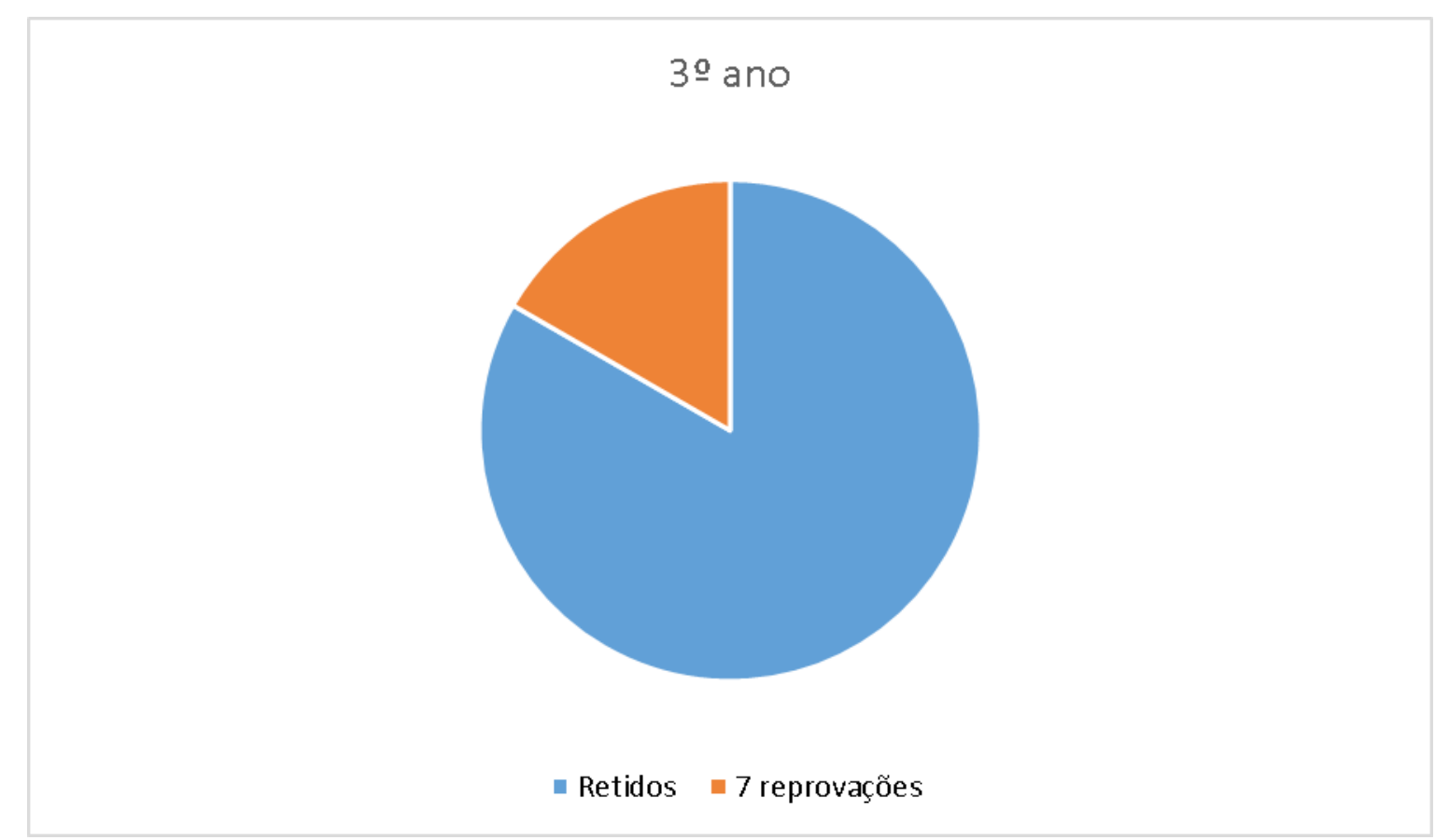

Fonte: Elaborada pelos autores.

\subsection{INGRESSO EM 2009:}

No ano de 2009, o total de ingressantes foi de 69, assim como no ano anterior. Deste total, $71 \%$ (49) dos estudantes se formaram, os $29 \%$ (20) restantes não se formaram. 


\section{Revista Thema}

\begin{tabular}{l|l|l} 
v.19 & n.3 & 2021
\end{tabular}

Figura 13 - Situação dos estudantes ingressos do curso técnico de Gestão Cultural em 2009 do IFSul câmpus Sapucaia do Sul.

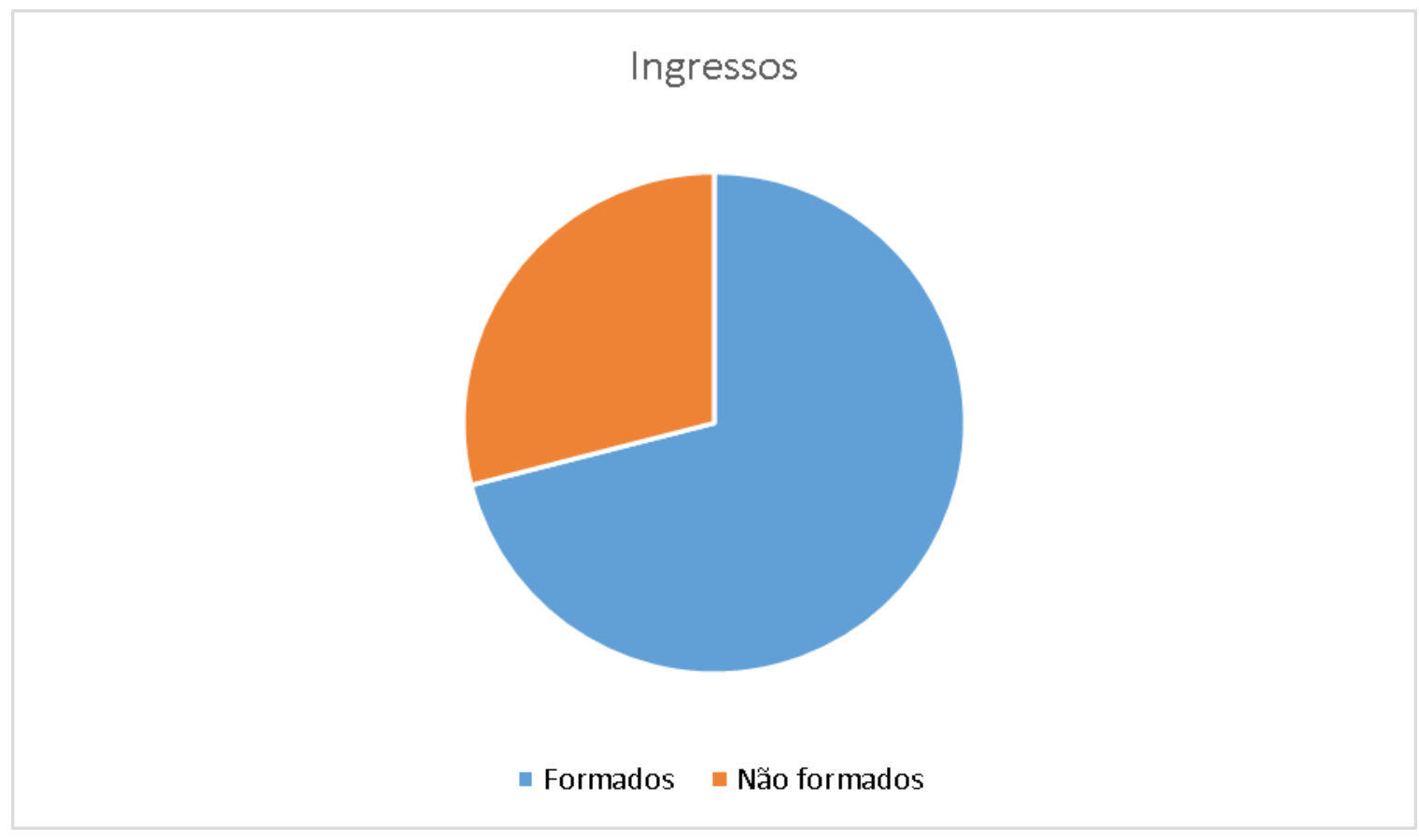

Fonte: Elaborada pelos autores.

Dos 29\% (no total de 20) que não se formaram, 60\% (12) evadiram, 30\% (6) cancelaram a matrícula e 10\% (2) transferiram-se de instituição.

Figura 14 - Situação dos estudantes não formados no curso de Gestão Cultural em 2009 do IFSul câmpus Sapucaia do Sul.

\section{Não formados}

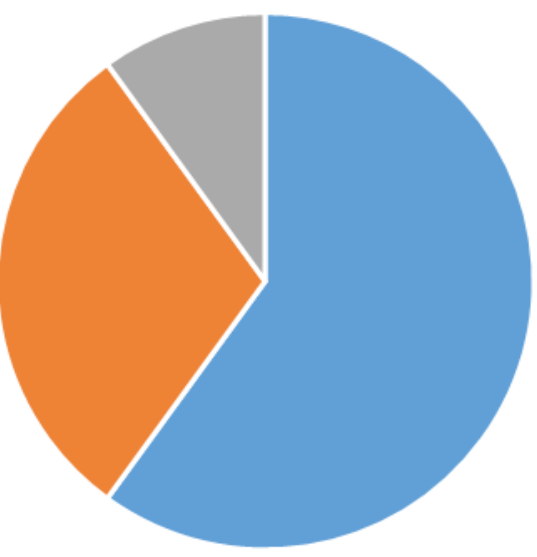

- Evasões - Cancelamentos = Transferências

Fonte: Elaborada pelos autores. 


\section{Revista Thema}

V.19

\begin{tabular}{l|l} 
n.3 & 2021
\end{tabular}

Considerando quando ocorreu o desligamento, $40 \%$ (8) se desligaram no 1 o ano, $30 \%$ (6) no 2 o ano, $15 \%$ (3) no 3 ano e $15 \%$ (3) no 4 e último ano.

Figura 15 - Situação dos estudantes com desligamentos no curso de Gestão Cultural em 2008 do IFSul câmpus Sapucaia do Sul.

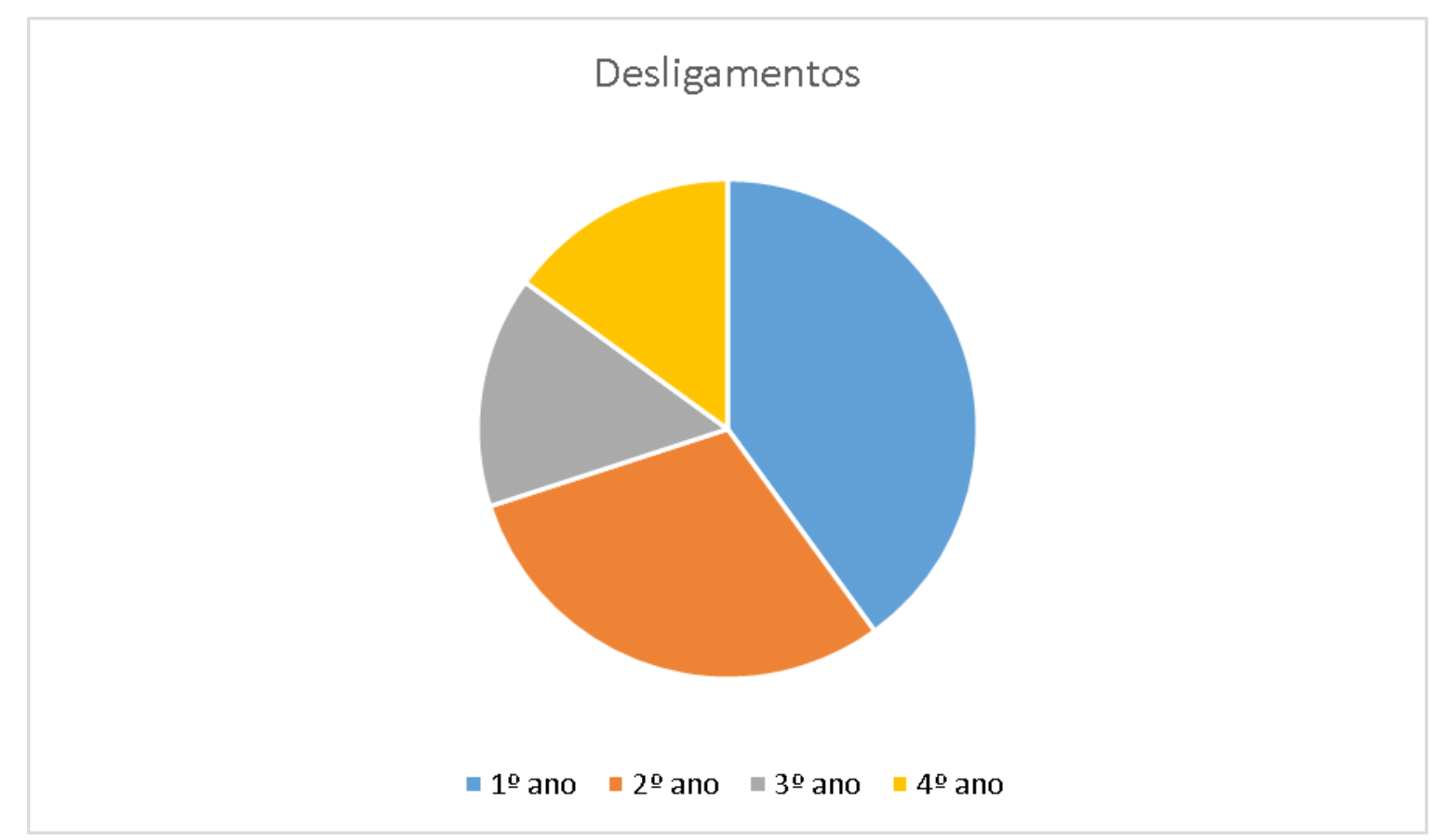

Fonte: Elaborada pelos autores.

Figura 16 - Situação dos estudantes evadidos no curso técnico de Gestão Cultural em 2009 do IFSul câmpus Sapucaia do Sul.

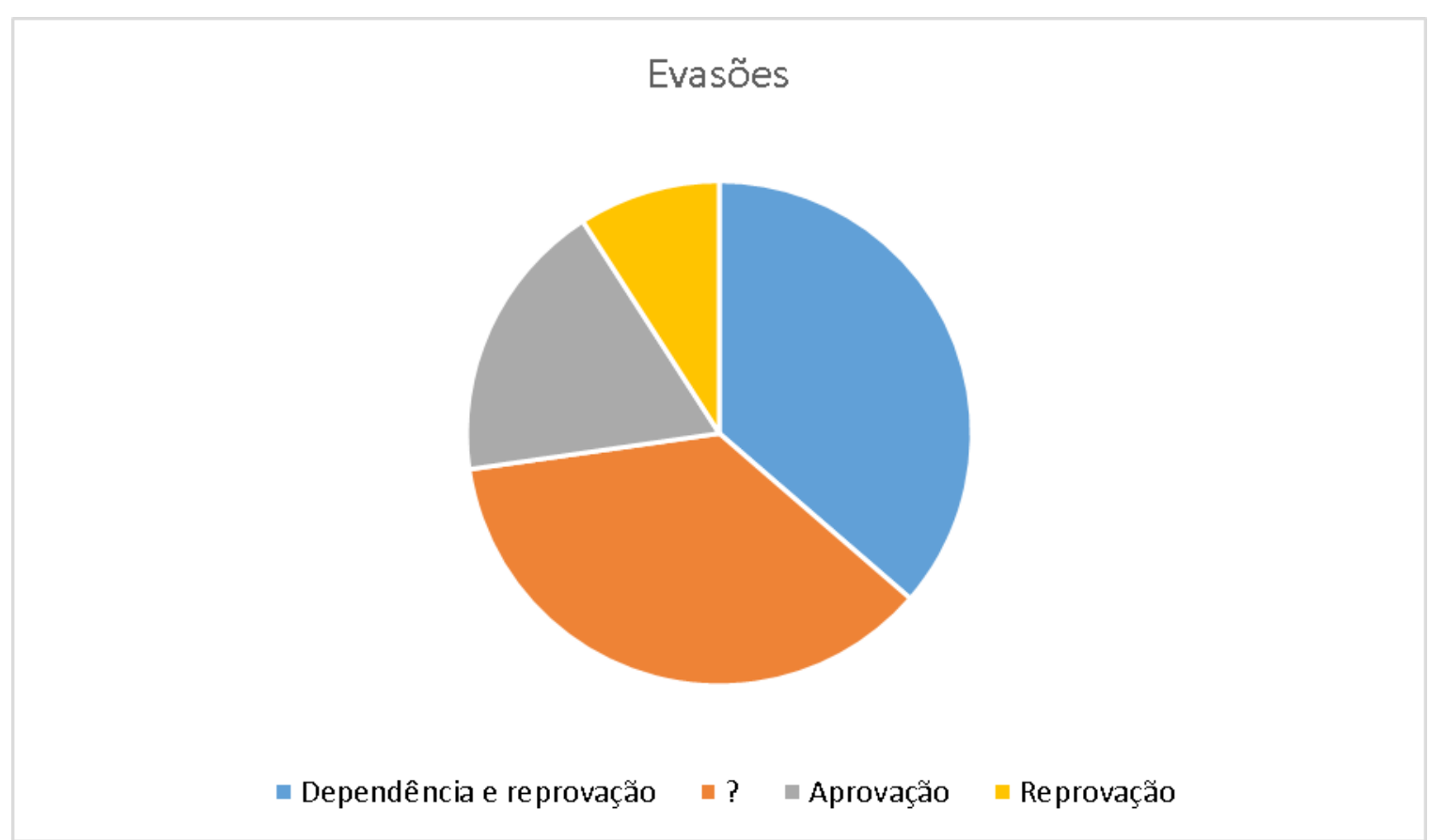

Fonte: Elaborada pelos autores. 


\section{Revista Thema}

v.19

\begin{tabular}{l|l} 
n.3 & 2021
\end{tabular}

Figura 17 - Situação dos estudantes com cancelamentos no curso técnico de Gestão Cultural em 2009 do IFSul câmpus Sapucaia do Sul.

\section{Cancelamentos}

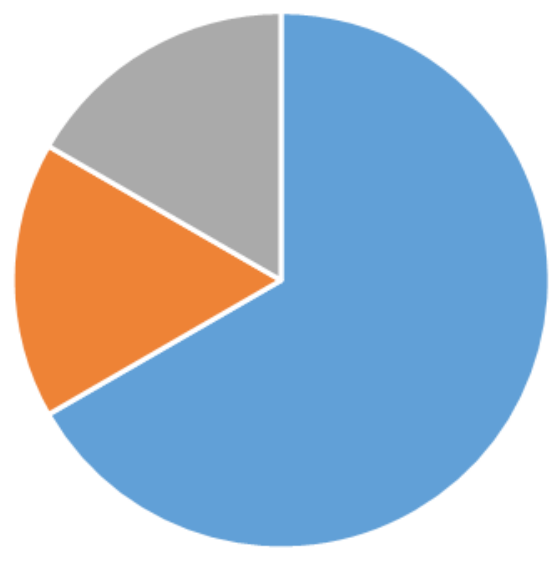

" Reprovação " ? Dependência

Fonte: Elaborada pelos autores.

Figura 18 - Situação dos estudantes com transferências externas no curso de Gestão Cultural em 2009 do IFSul câmpus Sapucaia do Sul.

\section{Transferidos externamente}

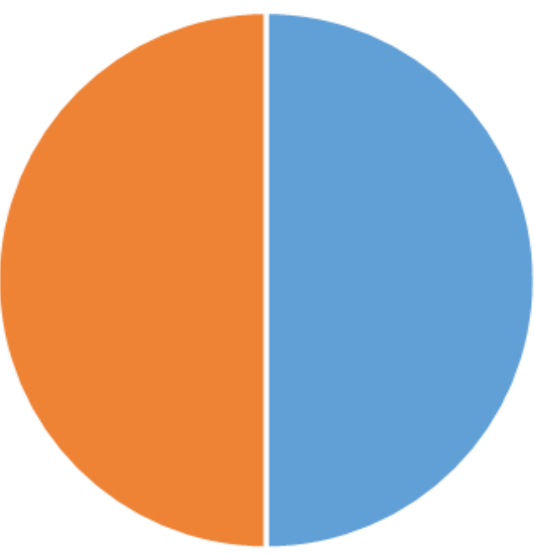

- Reprovação " Dependência

Fonte: Elaborada pelos autores.

Dos evadidos (60\% e total de 12 estudantes), 37\% (4) possuíam dependência e reprovação, 36\% (4) não fora constatado o histórico de rendimento, $18 \%$ (2) tinham aprovação e $9 \%$ (1) tinha apenas reprovação. 


\section{Revista Thema}

V.19

Dos cancelados ( $30 \%$ no total de 12 ), $67 \%$ (4) possuíam reprovação, $17 \%$ (1) não tinham motivo e $16 \%$ (1) tinham dependência.

Dos transferidos de forma externa (10\%), 50\% (1) tinham reprovação e $50 \%$ (1) tinha dependência.

\subsection{INGRESSO EM 2010}

O número de ingressantes em 2010 foi de 69 estudantes. Deste total, 67\% (46) se formaram e os outros 33\% (23) não se formaram.

Figura 19 - Situação dos estudantes ingressos no curso técnico de Gestão Cultural em 2010 do IFSul câmpus Sapucaia do Sul.

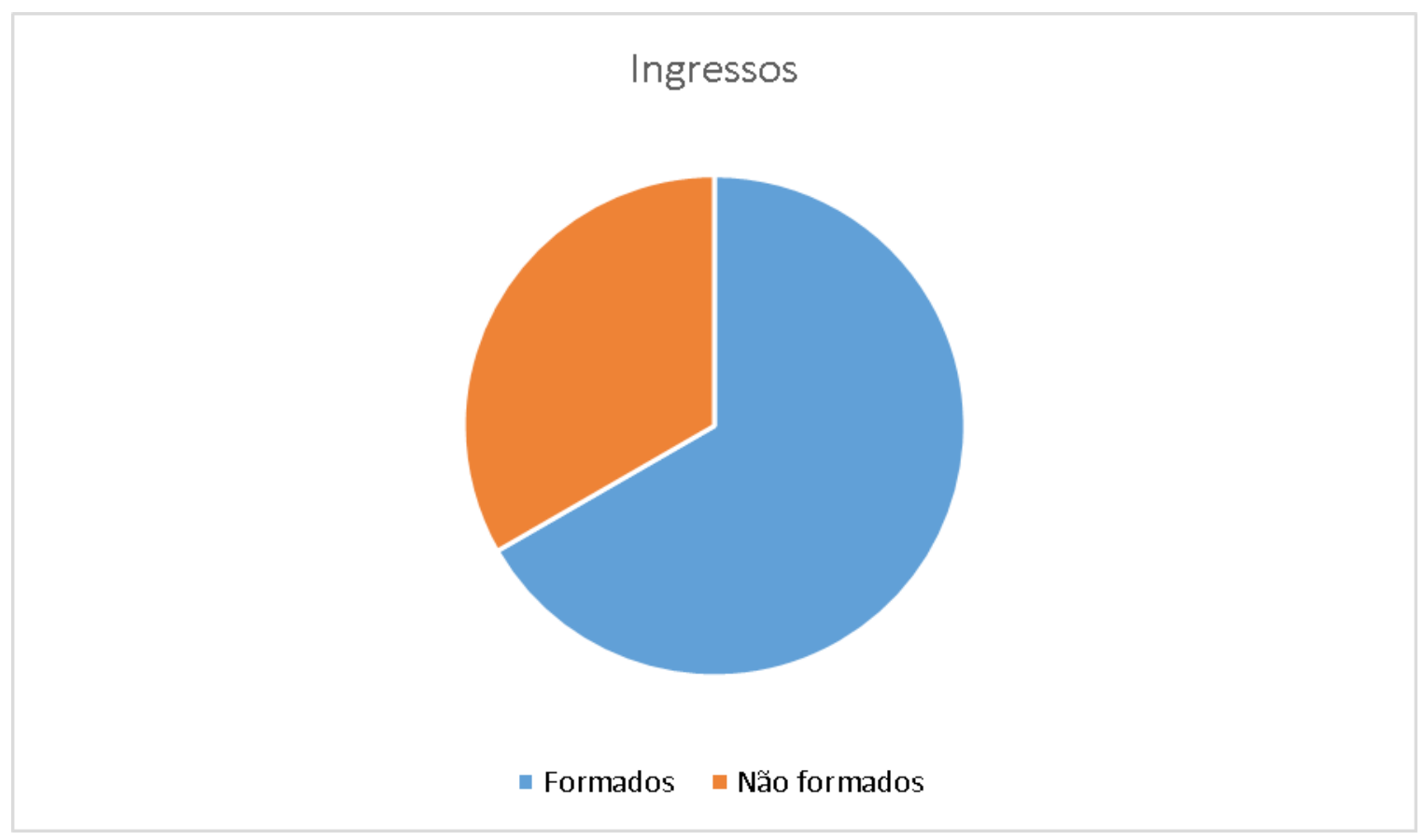

Fonte: Elaborada pelos autores.

Dos $67 \%$ (total de 46) que se formaram, $87 \%$ (40) se formou nos 4 anos regulares, $11 \%$ (5) se formaram em 5 anos e 2\% (1) se formaram em 3 anos. Dos 33\% que não se formaram, $57 \%$ (13) evadiram, $26 \%$ (6) foram transferidos e $17 \%$ (4) cancelaram a matrícula.

Do total que não se formaram (33\%, no total de 23), 39\% (9) se desligaram no 20 ano, $31 \%$ (7) se desligaram no 3 을 ano, $26 \%$ (6) se desligaram no 1 o ano e $4 \%$ (1) se desligaram no 4음 ano.

Dos evadidos (57\%, no total de 13 ), 42\% (5) possuíam reprovação, 33\% (4) tinham dependência e reprovação, $17 \%$ (2) tinham dependência e $8 \%$ (1) tinham apenas aprovação. 


\section{Revista Thema}

\begin{tabular}{l|l|l} 
v.19 & n.3 & 2021
\end{tabular}

Figura 20 - Situação dos estudantes formados no curso técnico de Gestão Cultural em 2010 do IFSul câmpus Sapucaia do Sul.

Formados

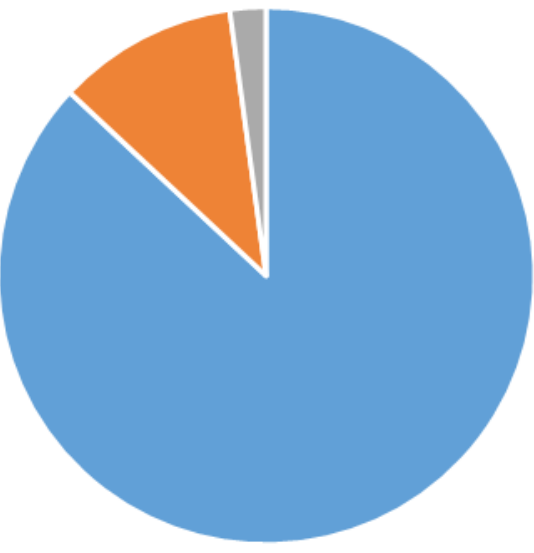

- 4 anos $\quad 5$ anos -3 anos

Fonte: Elaborada pelos autores.

Figura 21 - Situação dos estudantes não formados no curso de Gestão Cultural em 2010 do IFSul câmpus Sapucaia do Sul.

Não formados

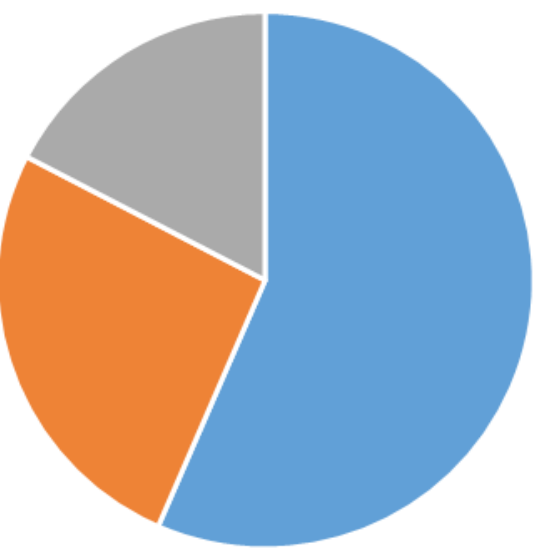

- Evasões = Transferências = Cancelamentos

Fonte: Elaborada pelos autores. 


\section{Revista Thema}

Figura 22 - Situação dos estudantes com desligamentos no curso técnico de Gestão Cultural em 2010 do IFSul câmpus Sapucaia do Sul.

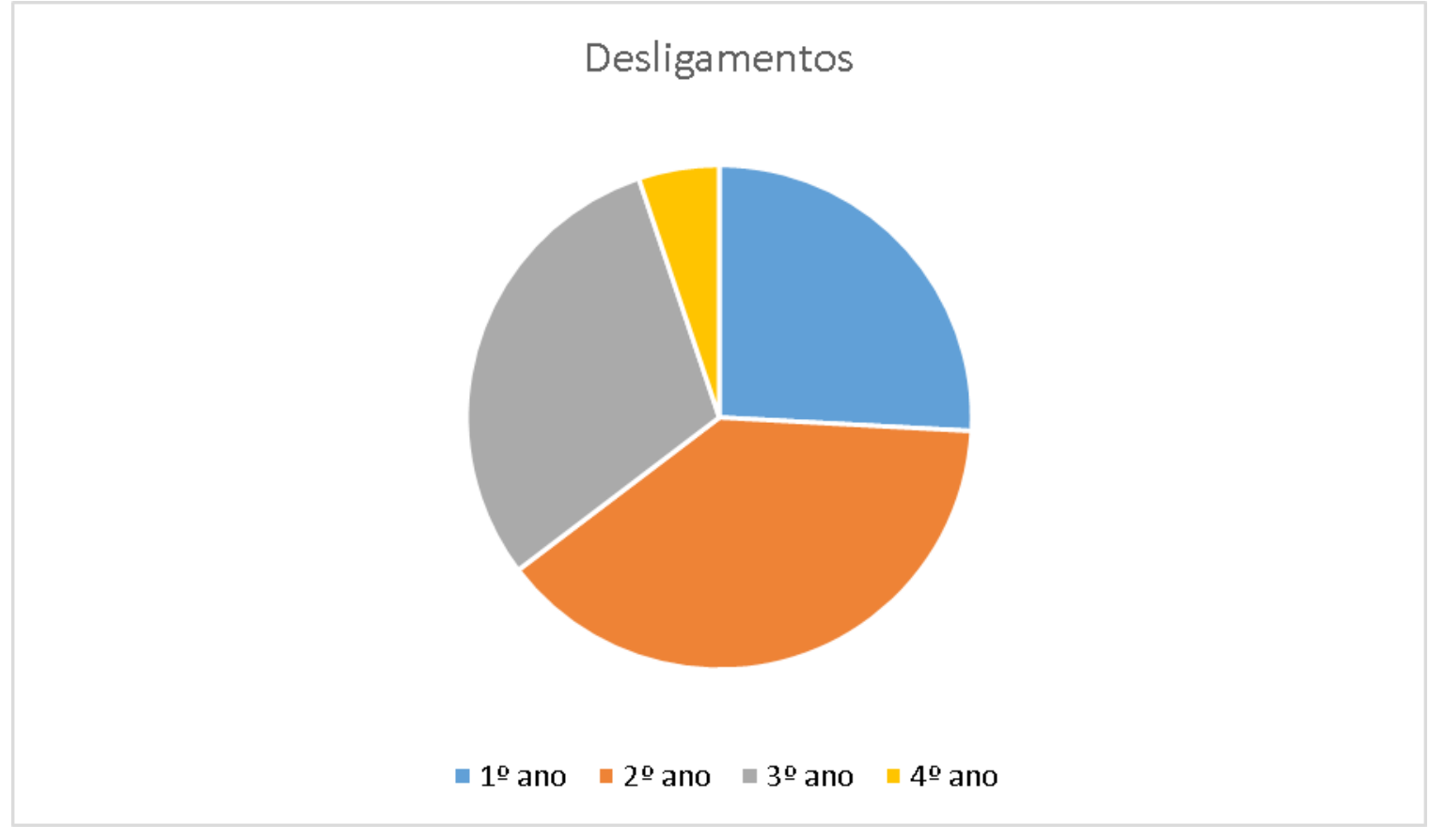

Fonte: Elaborada pelos autores.

Figura 23 - Situação dos estudantes evadidos no curso técnico de Gestão Cultural em 2010 do IFSul câmpus Sapucaia do Sul.

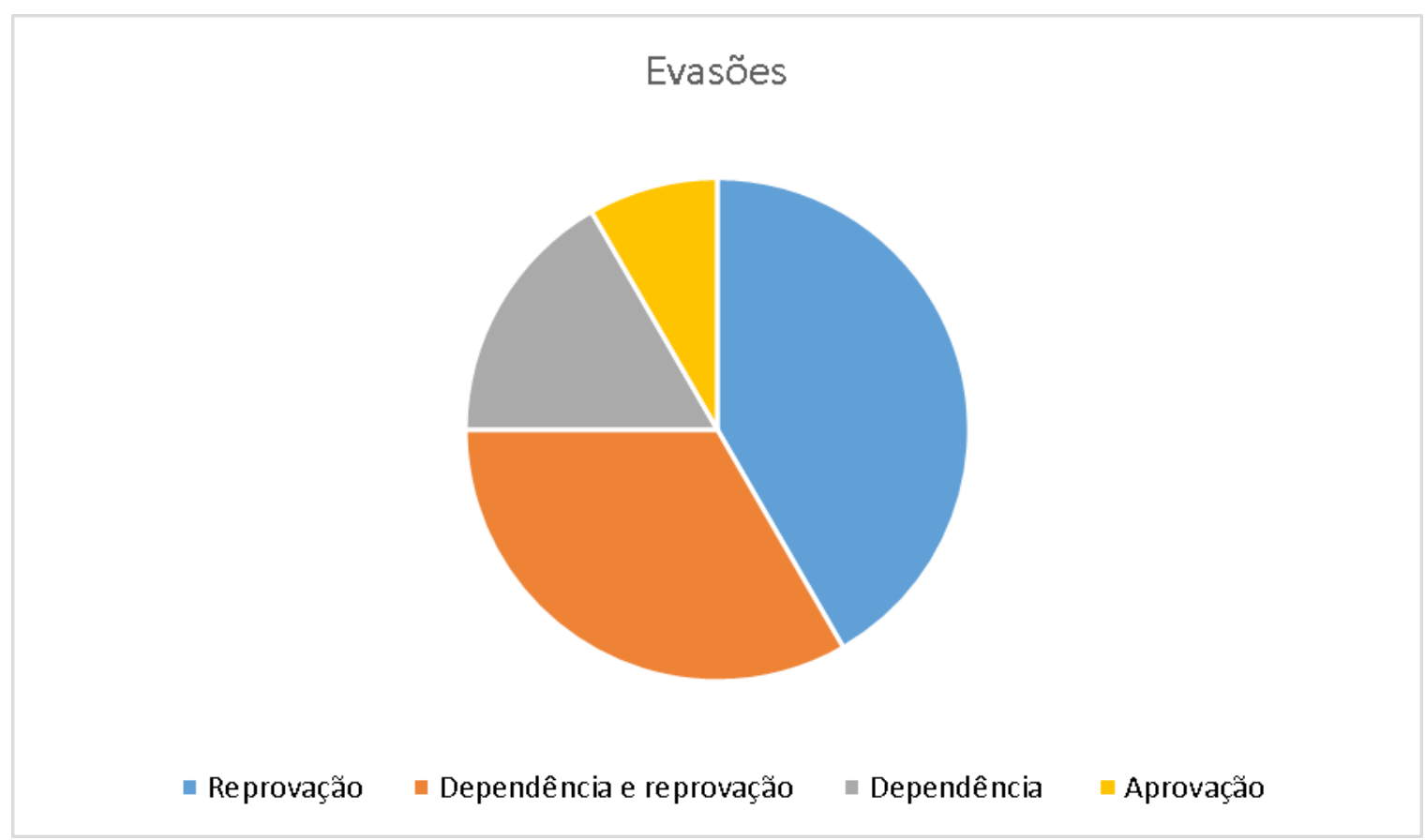

Fonte: Elaborada pelos autores.

Dos cancelados ( $17 \%$ no total de 04 ), $50 \%$ (2) tinham reprovação, $25 \%$ (1) não tinham reprovação e $25 \%$ (1) apenas cancelou. 


\section{Revista Thema}

V.19

\begin{tabular}{l|l} 
n.3 & 2021
\end{tabular}

Figura 24 - Situação dos estudantes com cancelamentos no curso técnico de Gestão Cultural em 2010 do IFSul câmpus Sapucaia do Sul.

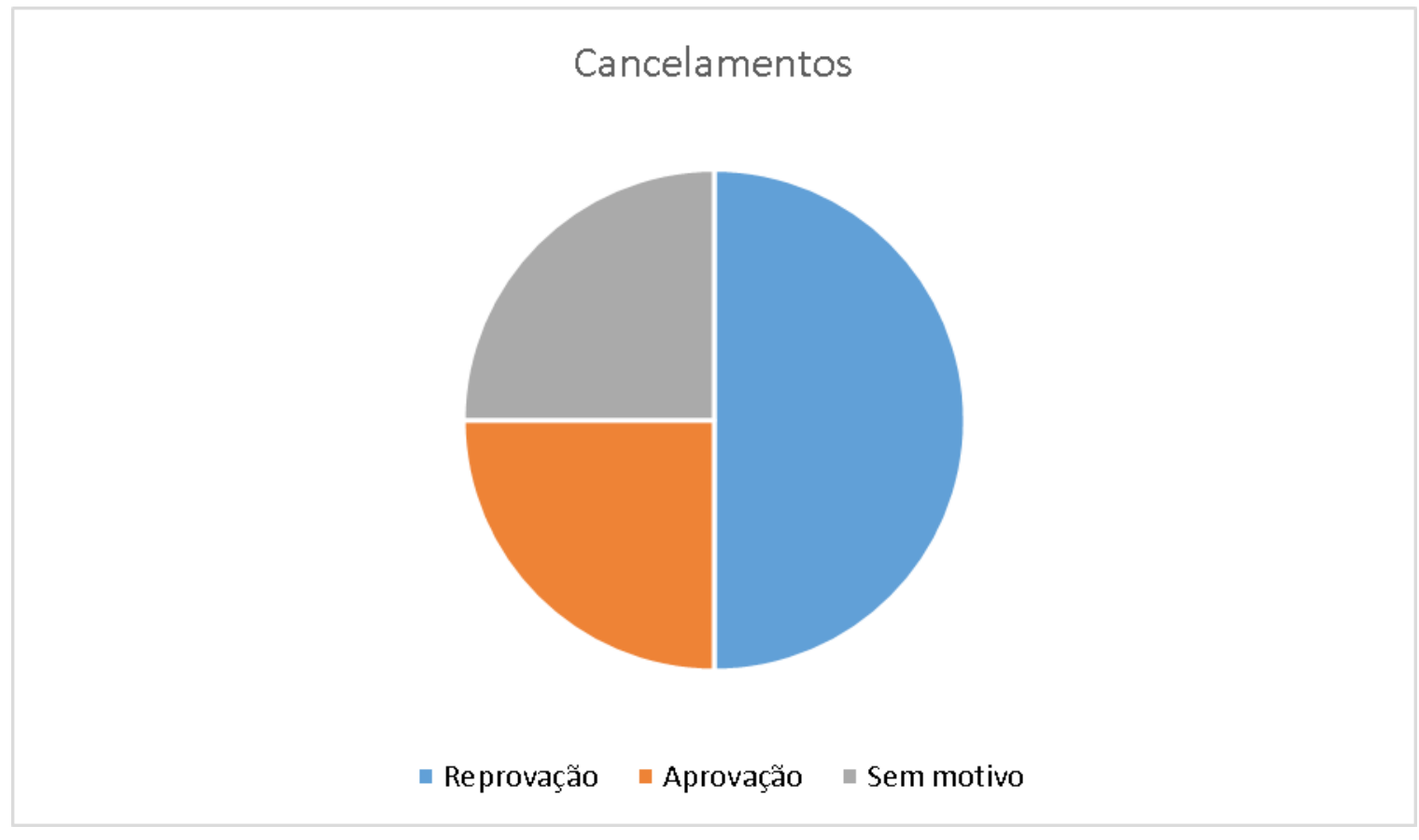

Fonte: Elaborada pelos autores.

Dos transferidos (26\% no total de 06), 50\% (3) tinha aprovação, $17 \%$ (1) tinha reprovação e dependência, 17\% (1) apenas transferiu-se e 16\% (1) tinha dependência.

Figura 25 - Situação dos estudantes com transferências no curso técnico de Gestão Cultural em 2010 do IFSul câmpus Sapucaia do Sul.

\section{Transferências}

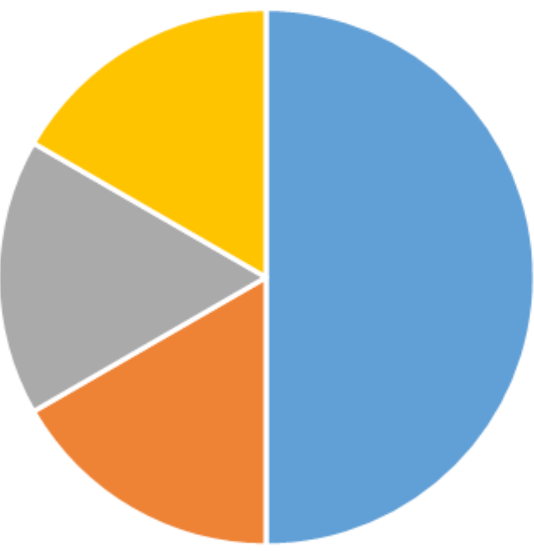

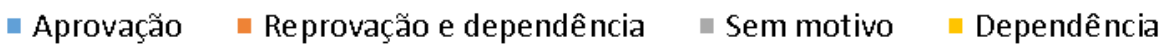

Fonte: Elaborada pelos autores. 


\section{Revista Thema}

V.19

\begin{tabular}{l|l} 
n.3 & 2021
\end{tabular}

\subsection{INGRESSO EM 2011}

O número de ingressos em 2011 foi de 69 estudantes. Do total de ingressantes, 67\% (46) se formou e 33\% (23) não se formaram.

Figura 26 - Situação dos estudantes ingressos no curso técnico de Gestão Cultural em 2011 do IFSul câmpus Sapucaia do Sul.

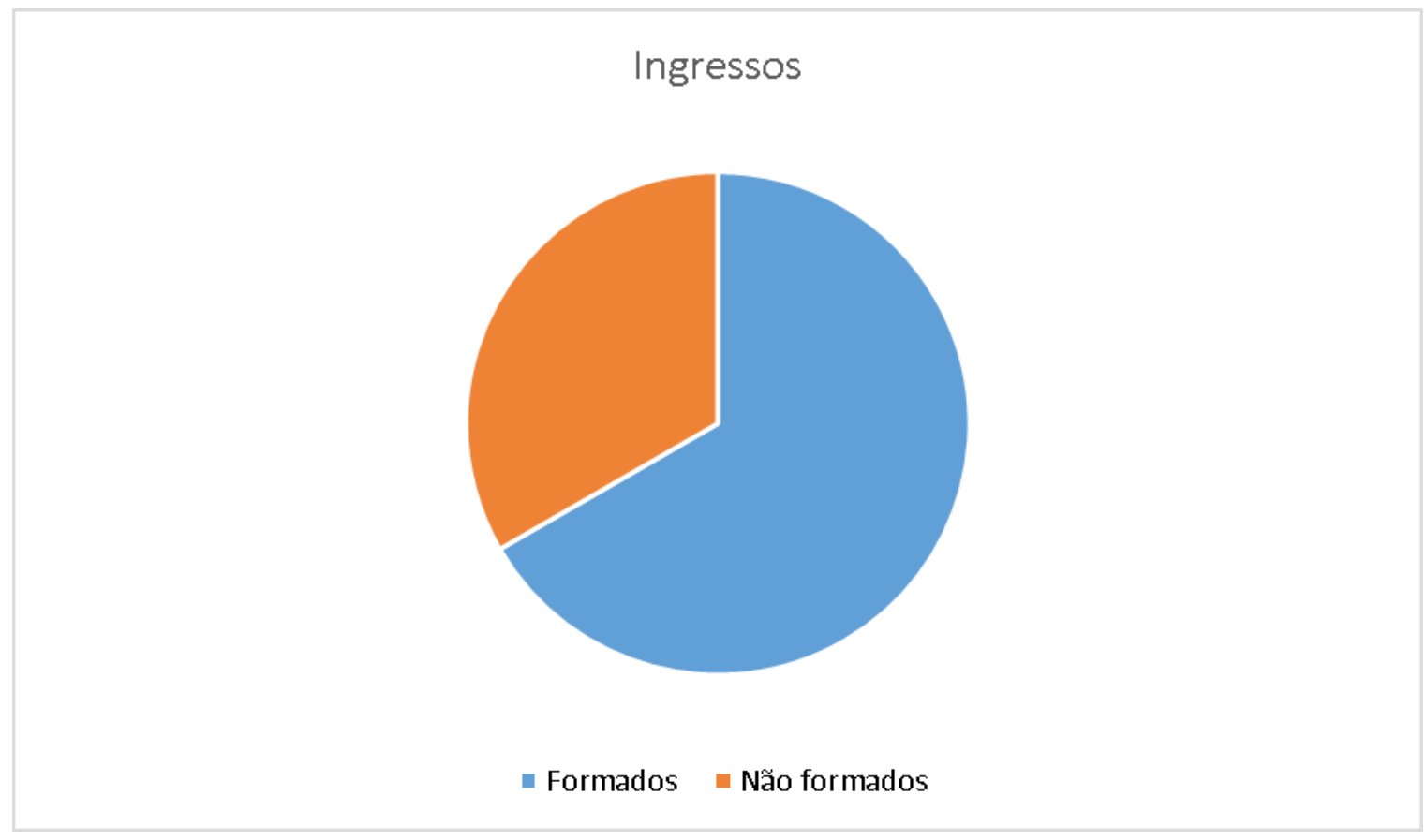

Fonte: Elaborada pelos autores.

Figura 27 - Situação dos estudantes não formados no curso técnico de Gestão Cultural em 2011 do IFSul câmpus Sapucaia do Sul.

\section{Não formados}

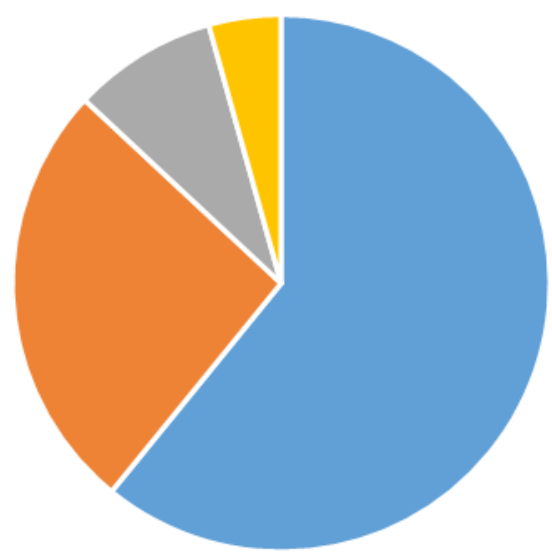

Evasões $\quad$ Cancelamentos $\quad$ Transferências $\square$ Troca de grade 


\section{Revista Thema}

V.19

\begin{tabular}{l|l} 
n.3 & 2021
\end{tabular}

Dos não formados (33\% no total de 23), 61\% (14) evadiram, 26\% (6) cancelaram, $9 \%$ (2) transferiram e $4 \%$ (1) tiveram troca de grade.

Figura 28 - Situação dos estudantes com desligamentos no curso técnico de Gestão Cultural em 2011 do IFSul câmpus Sapucaia do Sul.

\section{Desligamentos}

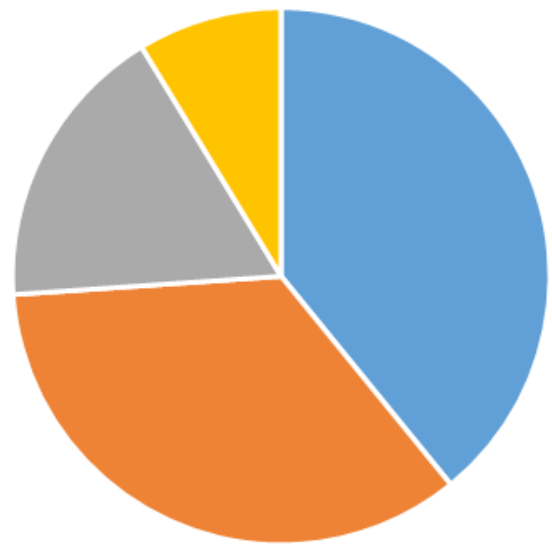

$\because 3^{\mathrm{o}}$ ano $\because 1^{\mathrm{o}}$ ano $\square 2^{\mathrm{o}}$ ano $\amalg 4^{\mathrm{o}}$ ano

Fonte: Elaborada pelos autores.

Figura 29 - Situação dos estudantes evadidos no curso técnico de Gestão Cultural em 2011 do IFSul câmpus Sapucaia do Sul.

\section{Evasões}

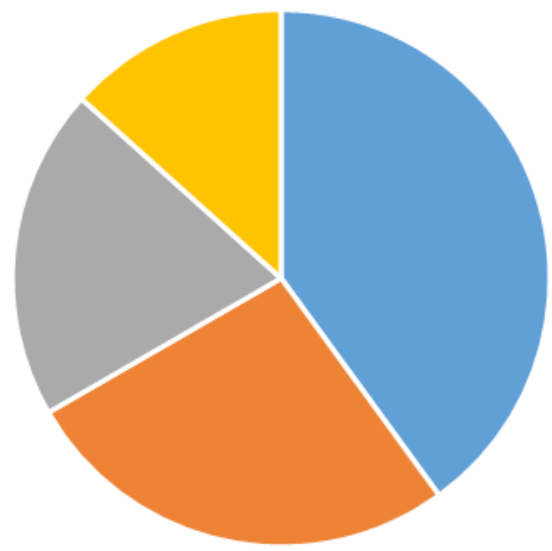

- Reprovação = Aprovações = Dependência - Dependência e reprovação

Fonte: Elaborada pelos autores. 


\section{Revista Thema}

V.19

Além disso, dos 33\% (no total de 23) que não se formaram, 39\% (9) se desligaram no 3ㅇ ano, $35 \%$ (8) no 1ㅇano, $17 \%$ (4) no 2 o ano e $9 \%$ (2) no 4 o ano.

Figura 30 - Situação dos estudantes com cancelamentos no curso técnico de Gestão Cultural em 2011 do IFSul câmpus Sapucaia do Sul.

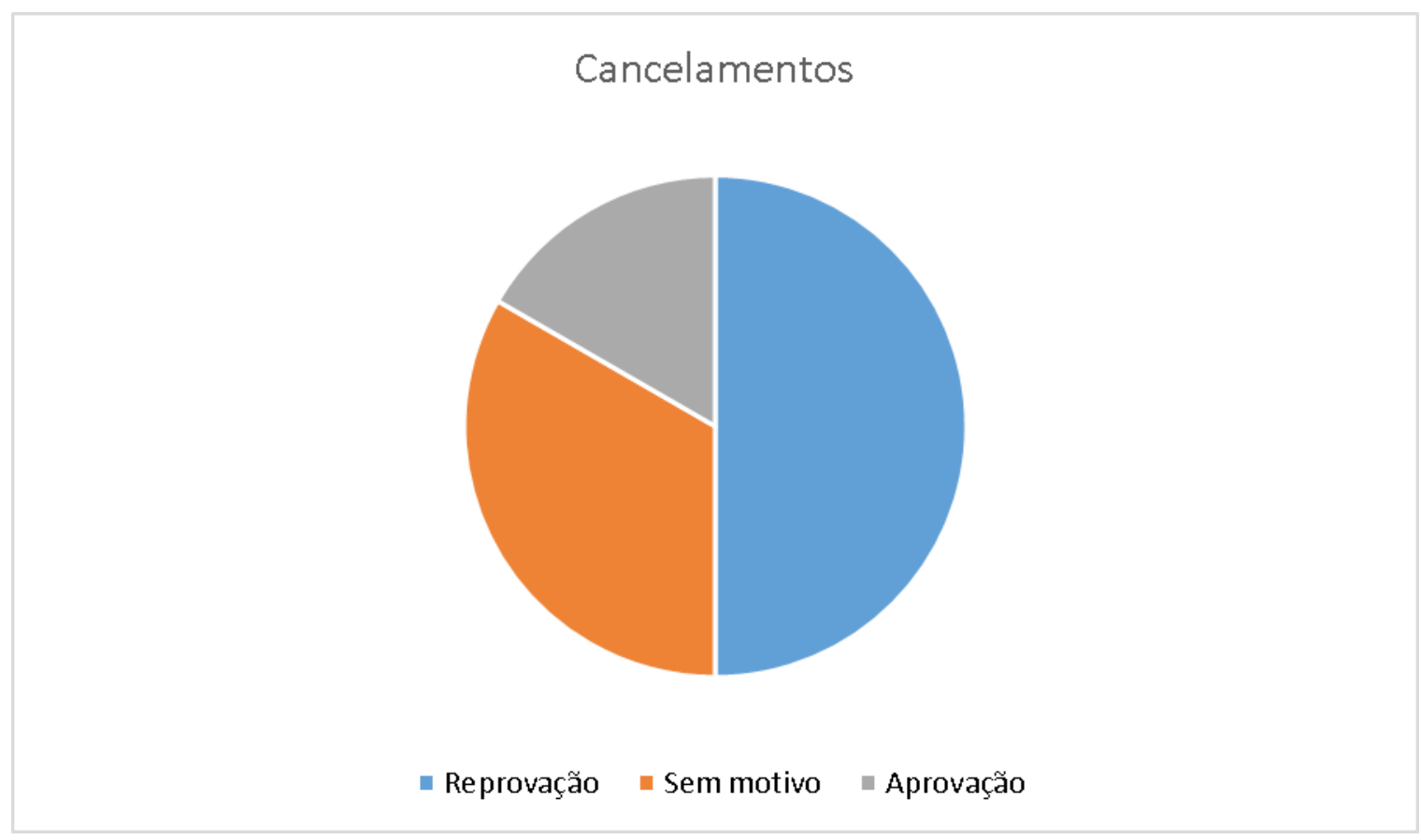

Fonte: Elaborada pelos autores.

Figura 31 - Situação dos estudantes com transferências do curso técnico de Gestão Cultural em 2011 do IFSul câmpus Sapucaia do Sul.

Transferências

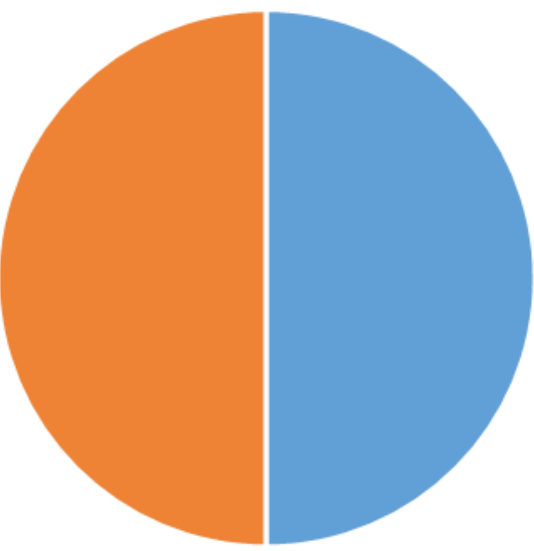

- Aprovação neprovação

Fonte: Elaborada pelos autores. 


\section{Revista Thema}

V.19

Dos $61 \%$ (no total de 14) que evadiram, 40\% (6) tinham reprovação, $27 \%$ (4) eram aprovados, 20\% (3) tinham dependência e 13\% (2) tinham dependência e reprovação.

Dos $26 \%$ (no total de 6) que cancelaram a matrícula, 50\% (3) tinham reprovação, 33\% (2) apenas cancelaram e $17 \%$ (1) não tinham reprovação.

Os $9 \%$ que se transferiram, $50 \%$ (1) tinha aprovação e os outros $50 \%$ (1) tinha reprovação.

\subsection{INGRESSO EM 2012}

O número de ingressantes foi de 70 estudantes no ano de 2012. Deste total, 79\% (55) se formaram e $21 \%$ (15) não se formaram.

Figura 32 - Situação dos estudantes ingressos no curso técnico de Gestão Cultural em 2012 do IFSul câmpus Sapucaia do Sul.

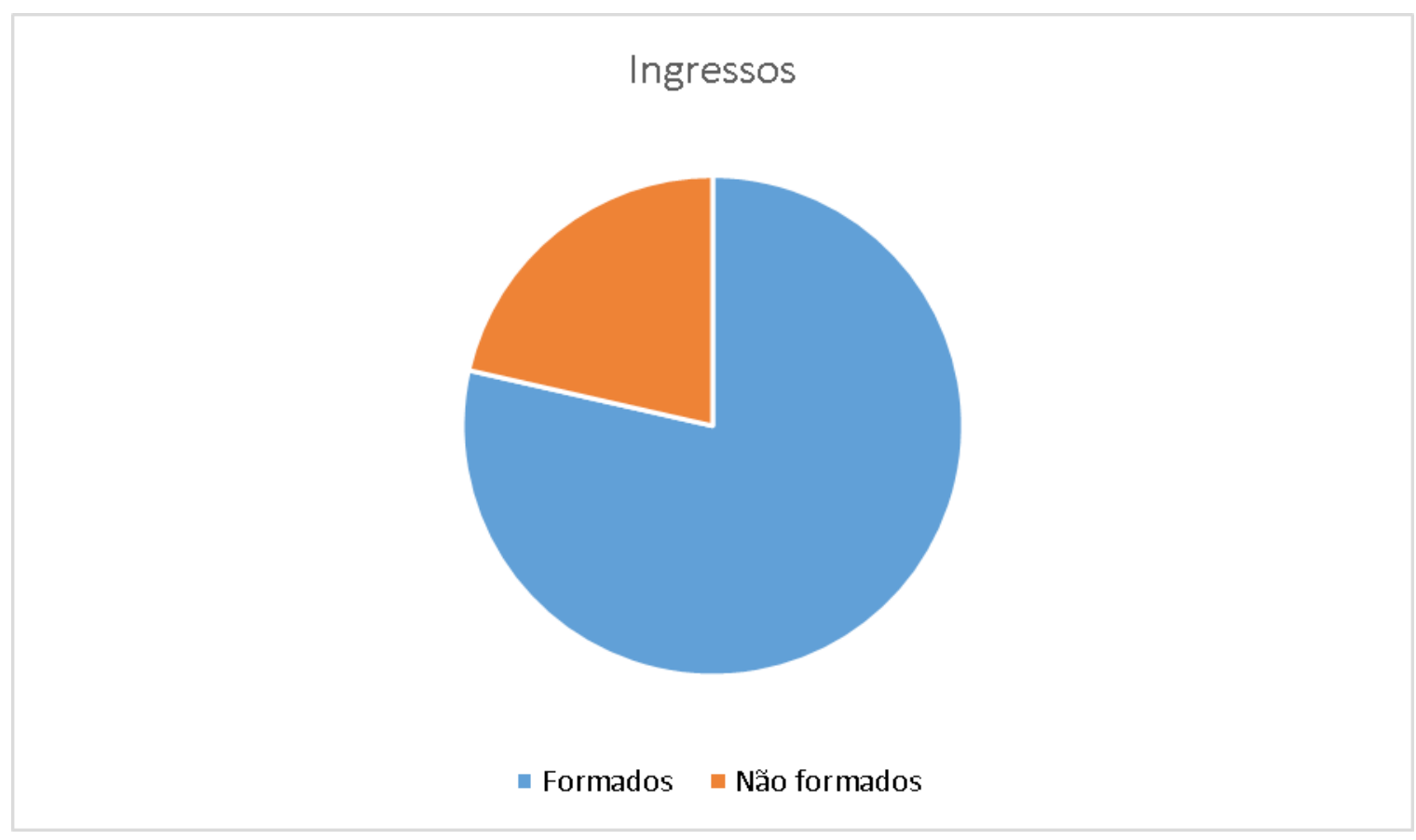

Fonte: Elaborada pelos autores.

Com relação aos desligados do curso, 40\% (6) trocaram de grade, 33\% (5) evadiram, $20 \%$ (3) pediram transferência e $7 \%$ (1) cancelaram a matrícula. Com relação ao ano de desligamento, $33 \%$ (5) eram do 2 o ano, $27 \%$ (4) eram do 1 o ano e $27 \%$ (4) eram do

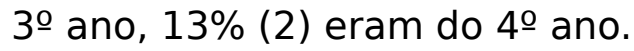

Com relação ao desempenho dos evadidos, 40\% (2) tinham dependência, 20\% (1) tinham dependência e reprovação, $20 \%$ (1) eram aprovados e $20 \%$ (1) eram reprovados.

Dos $20 \%$ que se transferiram, 34\% (1) tinham reprovação, 33\% (1) eram aprovados e $33 \%$ (1) tinham reprovação e dependência. 


\section{Revista Thema}

V.19

\begin{tabular}{l|l} 
n.3 & 2021
\end{tabular}

Figura 33 - Situação dos estudantes não formados no curso técnico de Gestão Cultural em 2012 do IFSul câmpus Sapucaia do Sul.

\section{Não formados}

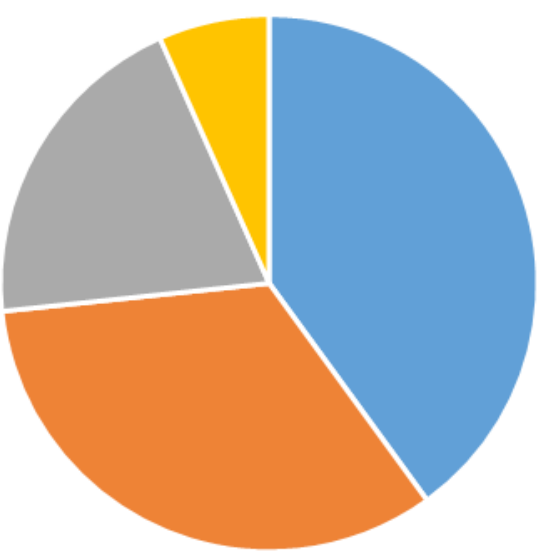

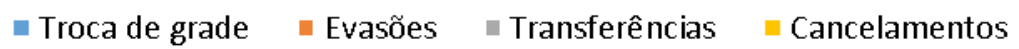

Fonte: Elaborada pelos autores.

Figura 34 - Situação dos estudantes com desligamentos no curso técnico de Gestão Cultural em 2012 do IFSul câmpus Sapucaia do Sul.

\section{Desligamentos}

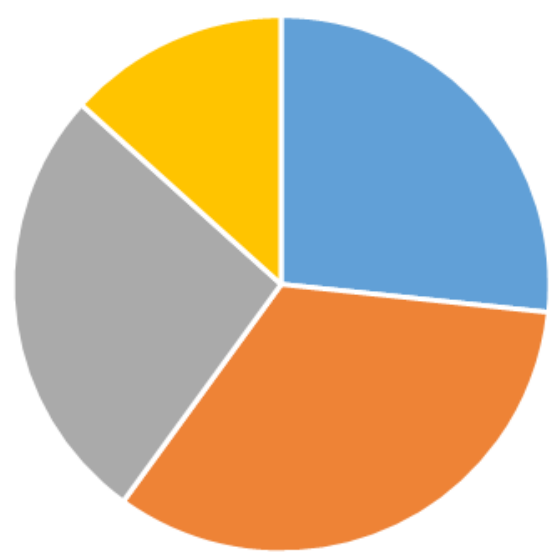

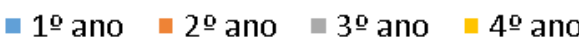

Fonte: Elaborada pelos autores. 


\section{Revista Thema}

Figura 35 - Situação dos estudantes evadidos no curso técnico de Gestão Cultural em 2012 do IFSul câmpus Sapucaia do Sul.

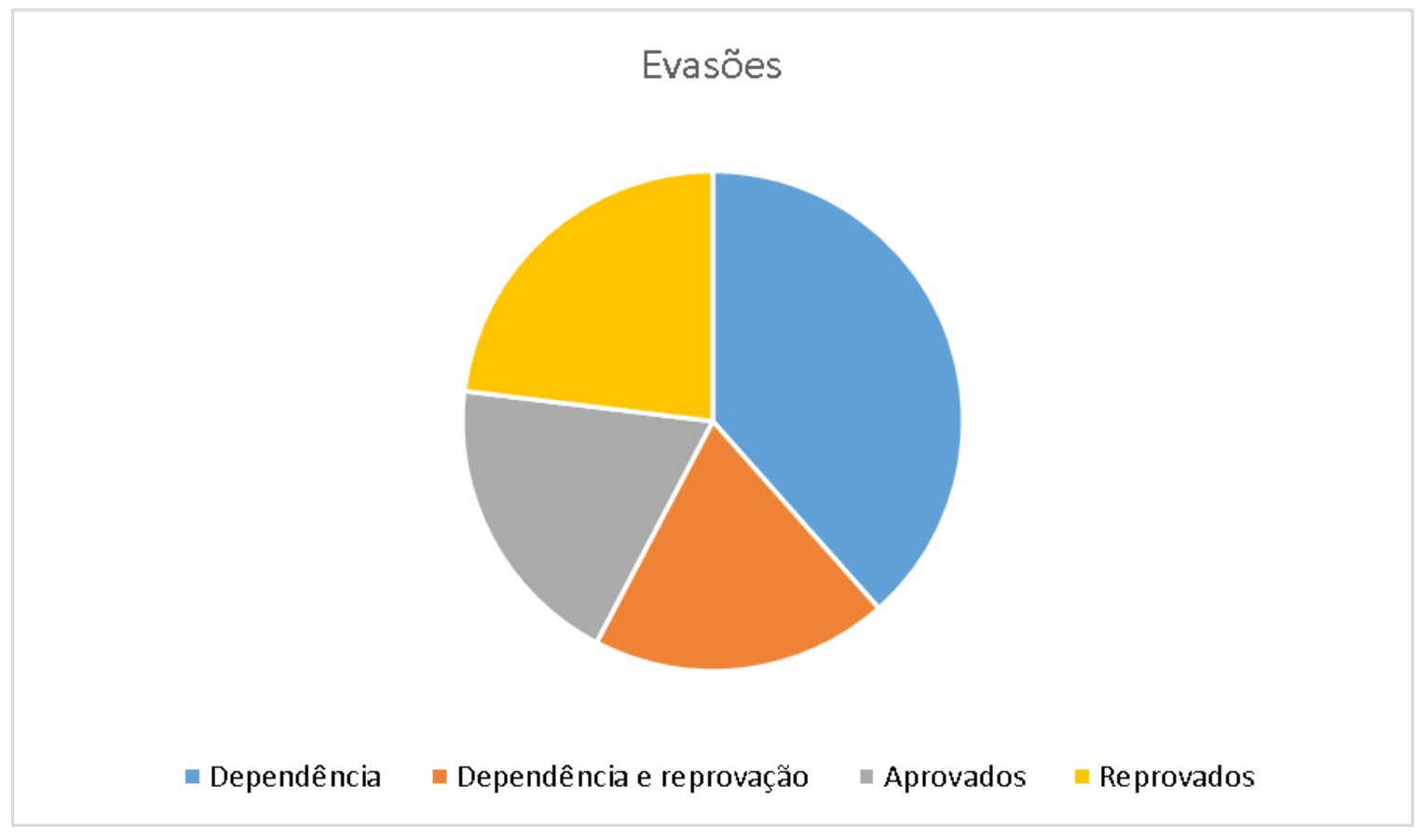

Fonte: Elaborada pelos autores.

Figura 36 - Situação dos estudantes com transferências no curso técnico de Gestão Cultural em 2012 do IFSul câmpus Sapucaia do Sul.

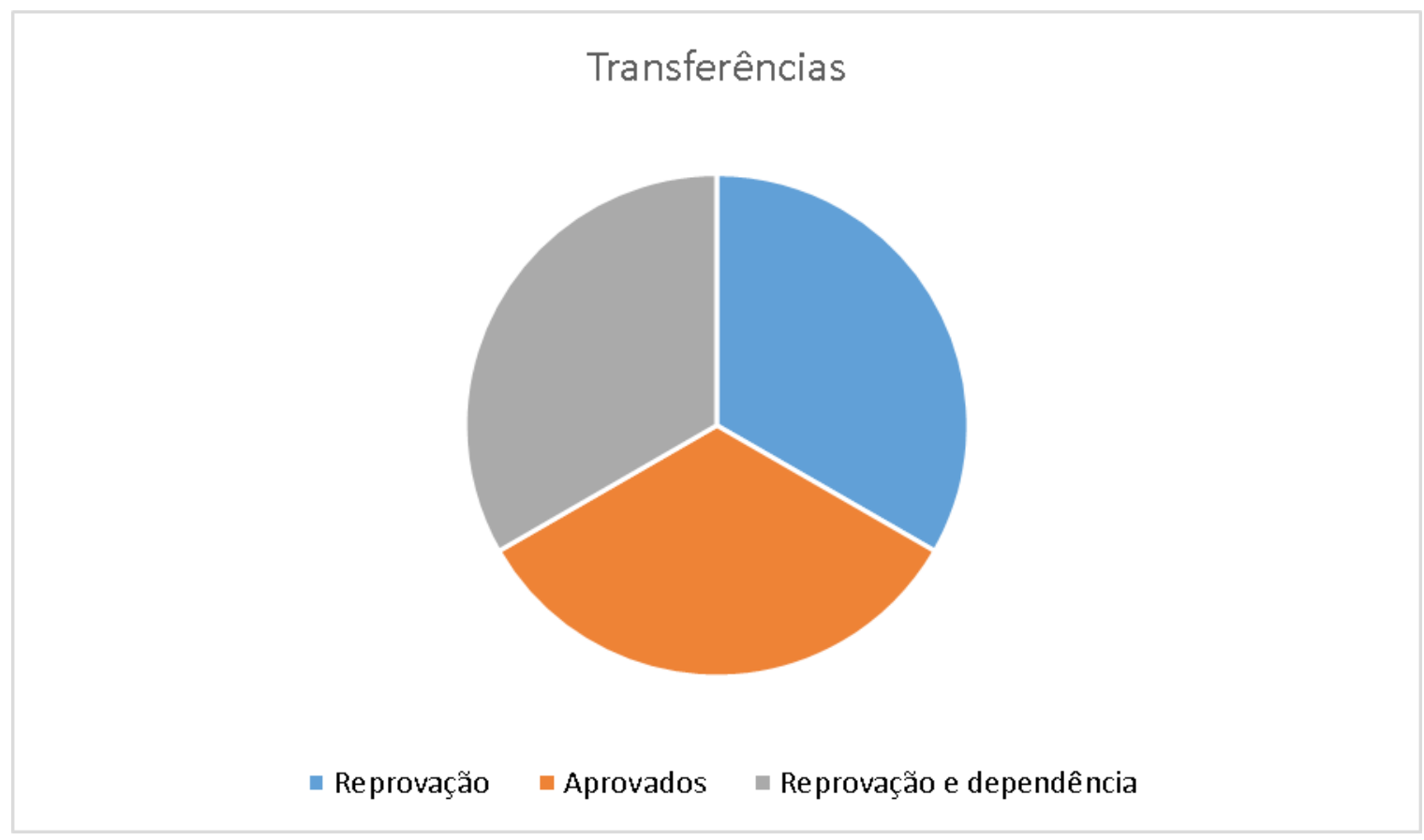

Fonte: Elaborada pelos autores.

De forma geral, em todos os anos analisados, o percentual de formados ficou acima do de não formados. Além disso, o ano em que teve mais estudantes formados foi 2012, onde o percentual alcançou quase $80 \%$ (55 estudantes) de um total de 70 estudantes. 
Todavia, por outro lado, o ano que teve mais estudantes não formados foi 2008 , tendo o percentual de $43 \%$ (30 estudantes) de um total de 69 estudantes.

Os anos e logo em seguida as séries onde mais ocorreram reprovações por infrequência dos alunos, foram: em 2008 o 1ㅇa, em 2009 o 3o e 4ㅇaㅅ anos, em 2010

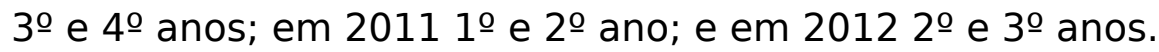

O ano que mais indicou casos de evasões foi 2008, seguido de 2011, 2010, 2009 e 2012. Com relação aos casos em que houve transferência externa, temos em primeiro lugar o ano de 2010, depois 2012, 2008, 2009 e 2011, onde estes três últimos anos empataram. No ranking de cancelamentos, temos: 2011 e 2009 empatados no primeiro lugar, 2008 e 2010 empatados no segundo lugar e, por fim, 2012.

\section{CONSIDERAÇÕES FINAIS}

Apesar da evasão escolar ser um problema tão grave e acarretar diversas consequências tanto para a sociedade quanto para o próprio individuo, tivemos como resultado que, em todos os anos analisados do curso de Gestão Cultural do IFSul (Instituto Federal Sul-rio-grandense), os casos de abandono escolar foram inferiores ao número de formados. Entretanto, os dados de evasões e reprovações assustam, levando em conta que os últimos podem servir de indício para futuras evasões.

O ano de 2008 foi o ano em que menos estudantes se formaram. Além disso, os desligamentos ocorreram mais no 1 을 e no 2 o ano. Tal fato pode ter ocorrido devido 0 ano de 2008 ser o primeiro ano de inserção do curso de Gestão Cultural.

O ano seguinte, 2009 , atingiu o percentual de $71 \%$ de estudantes formados, perdendo apenas para o ano de 2012 onde o percentual atingiu 79\%. Também foi neste ano em que teve mais estudantes formados no tempo regular de 4 anos. Apesar de o primeiro ano do curso apresentar um percentual baixo de estudantes formados, houve um crescimento deste percentual nos anos seguintes. Portanto, por serem das primeiras turmas, muitos estudantes abandonaram o curso talvez por falta de interesse ou confiança no mesmo.

Vale ressaltar que os desligamentos se deram mais no 1o ano de curso, tanto em 2008 quanto 2009, e houve poucos desligamentos no último, o 4ㅇa ano. Isto pode ter ocorrido pelo fato do aluno não se identificar com o curso logo no 1 o ano ou, em contrapartida, por se ver perto do término e optar por continuar até a conclusão do mesmo.

O fato dos alunos desligarem-se mais nos anos iniciais do curso nos anos de 2008 e 2009 corrobora com a ideia de Menezes-Filho e Leon (2003) citado anteriormente. Segundo ele, as ocorrências de evasões nas séries-diplomas, ou seja, último ano de curso, se dá em menor número quando comparado com as demais séries.

Em 2010 ocorreu uma queda relativamente pequena no número de formados, 4\% se comparado com o ano anterior. Diferentemente de 2008 e 2009, ocorreu mais desligamentos no 2 o ano e no 30 ano. Isto pode ter ocorrido pela necessidade de trabalho ou pela ocorrência de reprovações, sendo que $42 \%$ dos evadidos possuíam reprovações e 33\% possuíam reprovações e dependências. 
No ano seguinte, 2011, apenas 2\% (1 aluno) não se formou no tempo regular, se formando então em 5 anos. Contrapondo os anteriores, ocorreram mais casos de desligamentos no 3 o ano do que nos anos iniciais de curso. Além deste, outro fato curioso: do total de $57 \%$ de evadidos, 33\% não possuíam reprovações e nem dependências. O que pode explicar estes casos é a conclusão do ensino médio por meio do Exame Nacional do Ensino Médio (ENEM) ou a falta de engajamento com a instituição ou com o curso.

Diferentemente dos anos anteriores, em 2012 tiveram 70 alunos ingressos. Além disso, 2012 foi o único ano em que houve mais afastamentos por troca de grade do que por evasão. Destes que trocaram de grade, alguns eram reprovados e outros retidos. Até por termos a migração (troca) de curso em caso de reprovação, não sabendo se após a troca de curso ocorreu evasão ou conclusão.

Identificamos também que foram poucos os casos de evasão por parte de alunos sem reprovações ou dependências. Estes estudantes podem ter evadidos pela dificuldade de controlar as disciplinas reprovadas e as aprovadas, somado com a desmotivação causada pelas reprovações, tendo em vista que os evadidos possuíam histórico de reprovações em mais de 3 disciplinas.

Segundo dados divulgados pela revista IPEA (2007), os alunos que carregam na bagagem reprovações evadem mais porque acabam sentindo-se desmotivados e a cada ano reprovado, acabam por aprender menos ainda, levando as mesmas a abandonarem a escola posteriormente.

Entretanto, por mais que ocorreram poucos desligamentos no último ano, o 3ㅇ e o 4은 ano tiveram mais casos de reprovação por infrequência dos alunos. Devemos atentarnos à possibilidade de muitos alunos optarem por concluírem os estudos a partir da nota do ENEM (Exame Nacional do Ensino Médio), levando em consideração que nem todos os discentes ingressaram tendo interesse no curso técnico escolhido, podendo alguns deles querer apenas cursar o ensino médio com duração de 3 anos. Essa era uma possibilidade para a conclusão do Ensino Médio e ingressar no ensino superior.

Como continuidade dessa pesquisa seria interessante diagnosticar as razões que levaram os estudantes a se enquadrar em cada uma das categorias (evasão, transferido, cancelamento). Considerar o tipo de formação do curso também é um fator a ser considerado pois mudara o perfil de formação realizada na instituição e talvez impactando em números, considerados piores, no início da formação. Com o passar dos anos, a comunidade pôde compreender qual era a real formação do curso técnico integrado em Gestão Cultural. Outra questão que é importante considerarmos para futuras pesquisas e compreender os números de fracasso e êxito na educação profissional, é a concepção e intencionalidade da comunidade onde as instituições estão inseridas para a modalidade de cursos técnicos integrados. É comum ouvirmos que estudantes estão matriculados nos institutos pela qualidade de sua educação e a possibilidade de cursar uma graduação, sem qualquer importância para a formação técnica que está realizando.

É importante seguirmos com o diagnóstico sobre fracasso e êxito, principalmente sobre a evasão pois nos possibilitará diminuir os recursos desperdiçados e atender um quantitativo maior da população. 


\section{REFERÊNCIAS}

ARAÚJO, Cristiane F. de; SANTOS, Roseli A. dos. A educação profissional de nível médio e os fatores internos/externos às instituições que causam a evasão escolar. In: INTERNATIONAL CONGRESS ON UNIVERSITY - INDUSTRY COOPERATION, 4., Taubaté, 2012. Anais... Taubaté: UNINDU, 2012.

CARDOSO, Claudete Batista. Efeitos da política de cotas na Universidade de Brasília: uma análise do rendimento e da evasão. 2008. 134 f. Dissertação (Mestrado em Educação) - Universidade de Brasília, Brasília, 2008.

CRAVO, Ana Cristina. Análise das causas da evasão escolar do curso técnico de informática em uma faculdade de tecnologia de Florianópolis. Revista GUAL, Florianópolis, v.5, n.2, p.238-250, ago. 2012.

FORNARI, Liamara Teresinha. Reflexões acerca da reprovação e evasão escolar e os determinantes do capital. Revista Espaço Pedagógico, Passo Fundo, v.17, n.1, p.112-124, jan./jun. 2010.

GARSCHAGEN, Sérgio. O dilema da repetência e da evasão. Revista Desafios - IPEA, Brasília, n.36, p.34-45, out. 2007.

IFSul. Cursos Técnicos. Disponível em: http://www.sapucaia.ifsul.edu.br/cursos-emsapucaia. Acesso em: 03 out. 2018.

IFSUL. Câmpus Sapucaia. Disponível em: http://www.sapucaia.ifsul.edu.br/campussapucaia. Acesso em: 03 out. 2018.

JOHANN, Cristiane Cabral. Evasão escolar no instituo federal sul-rio-grandense: um estudo de caso no câmpus Passo Fundo. 2012. 119 f. Dissertação (Mestrado em Educação) - Universidade de Passo Fundo, Passo Fundo, 2012.

LEON, Fernanda Leite Lopez de; MENEZES-FILHO, Naércio Aquino. Reprovação, avanço e evasão escolar no Brasil. Pesquisa e planejamento econômico, São Paulo, v.32, n.3, p.416-452, 2002.

MACHADO, M. R. L.; MOREIRA, P. R. Educação profissional no Brasil, evasão escolar e transição para o mundo do trabalho. In: SEMINÁRIO NACIONAL DE EDUCAÇÃO PROFISSIONAL E TECNOLÓGICA, 3., 2012, Belo Horizonte. Anais... Belo Horizonte: Cefet-MG, 2012.

MEIRA, Cristiane Araujo. A evasão no Ensino Técnico Profissionalizante: um estudo de caso no Câmpus Cariacica do Instituto Federal do Espírito Santo. 2015. 118 f. Dissertação (Mestrado em Gestão Pública) - Universidade Federal do Espírito Santo, Vitória, 2015.

MOURA, Elisabete Martins; SILVA, João Carlos da. Reprovação escolar: discutindo mitos e realidades. Programa de Desenvolvimento Educacional (PDE) - UNICAMP. 2012. Disponível em: http://www.diaadiaeducacao.pr.gov.br/portals/pde/arquivos/370-2.pdf. Acesso em: 12 jun. 2019. 


\section{Revista Thema}

v.19

NUNES, Tatiene Germano Reis et al. Fatores de risco e proteção na escola: reprovação e expectativas de futuro de jovens paraenses. Revista Quadrimestral da Associação Brasileira de Psicologia Escolar e Educacional, São Paulo, v.18, n.2, p.203-210, mai./ago. 2014.

POLYDORO, Soely Aparecida Jorge. O trancamento de matrícula na trajetória acadêmica do universitário: condições de saída e de retorno à instituição. 2000. 179 f. Tese (Programa de Pós-graduação em Educação) - Universidade Estadual de Campinas, Campinas, 2000.

QUEIROZ, Lucileide Domingos. Um estudo sobre a evasão escolar: para se pensar a inclusão social. In: REUNIÃO ANUAL DA ANPED, 25., 2002, Caxambu. Anais... Caxambu: ANPED, 2002.

RUMBERGER, R.; LIMA, S. A. Why students drop out: a review of 25 years of research. California: University of California, 2008.

SILVA FILHO, Roberto Leal Lobo et al. A evasão no ensino superior brasileiro. Cadernos de Pesquisa, São Paulo, v.37, n.132, p.641-659, 2007.

SILVA FILHO, Raimundo Barbosa; ARAÚJO, Ronaldo Marcos de Lima. Evasão e abandono escolar na educação básica no Brasil: fatores, causas e possíveis consequências. Revista Educação Por Escrito, Porto Alegre, v.8, n.1, p.35-48, jan./jun. 2017. 